This PDF is a selection from an out-of-print volume from the National Bureau of Economic Research

Volume Title: Tax Policy and the Economy, Volume 14

Volume Author/Editor: James M. Poterba, editor

Volume Publisher: MIT Press

Volume ISBN: 0-262-66164-0

Volume URL: http://www.nber.org/books/pote00-2

Publication Date: January 2000

Chapter Title: Welfare Reform under PRWORA: Aid to Children with Working Families?

Chapter Author: Pamela Loprest, Stefanie Schmidt, Ann Dryden Witte

Chapter URL: http://www.nber.org/chapters/c10850

Chapter pages in book: (p. 157 - 203) 


\title{
Welfare Reform under PRWORA: Aid to Children with Working Families?
}

\author{
Pamela Loprest
}

Urban Institute

\section{Stefanie Schmidt}

Urban Institute

Ann Dryden Witte
Wellesley College, Florida International University, and NBER

\section{EXECUTIVE SUMMARY}

We assess some of the major themes and impacts of welfare reform that have emerged for states and families during the three years since the passage of the 1996 welfare reform bill, PRWORA. The major themes for states include: (1) a work-first approach to cash assistance, (2) large

This paper is a product of the Wellesley Child Care Research Partnership, the Child Care Bureau's Child Care Policy Research Consortium, and the Urban Institute's Assessing the New Federalism project. Our work was made possible by Grant 90 YE006 from the Child Care Bureau, Administration for Children \& Families, Department of Health and Human Services (DHHS); the Annie E. Casey Foundation; the W. K. Kellogg Foundation; the Henry J. Kaiser Family Foundation; the Ford Foundation; the John D. and Catherine T. MacArthur Foundation; the Charles Stewart Mott Foundation; the Commonwealth Fund; the Stuart Foundation; the Robert Wood Johnson Foundation; the Weingart Foundation; the McKnight Foundation; the Fund for New Jersey; and the Rockefeller Foundation. The authors would like to acknowledge the helpful comments of Magaly Queralt and Gina Adams. The opinion and conclusions of the paper should not be attributed to any of our funders or reviewers, or to any of the state and local areas with which we work. The authors alone are responsible for all errors. 
increases in federal funding for child care, (3) increasing diversity in state and local cash assistance and child-care programs, (4) the beginning stages of the integration of diverse child-care programs, and (5) the severing of the link between child-care assistance and cash assistance in some states. Changes for families include (1) increases in financial incentives to work; (2) mandatory work-related activity requirements, sanctions if requirements are not met, and time limits on cash-assistance receipt; (3) increased availability of child-care subsidies; and (4) a different environment and culture at welfare offices-stressing work and personal responsibility. Assessment of impacts on state and local government and low-income families with children are at an early stage. The clearest impact is the marked decline in the number of individuals receiving cash assistance and the equally marked increase in the number of children being cared for in nonfamilial settings. A markedly increased proportion of cash-assistance recipients are working or in other approved activities. Increased child-care subsidies appear to have increased the earnings of both current and former welfare recipients and other low-income families. Preliminary results suggest that work requirements and time limits have succeeded in moving low-income women with children into jobs, but have decreased the wages they are able to obtain compared to women who are not subject to time limits.

\section{INTRODUCTION}

The United States undertook a major reform of the welfare system with the passage of the Personal Responsibility and Work Opportunity Act (PRWORA) in August 1996. In passing PRWORA, legislators articulated the following goals for reform: (1) provide assistance to needy families so that children may be cared for in their own homes or in the homes of relatives; (2) end the dependence of needy parents on government benefits by promoting job preparation, work, and marriage; (3) prevent and reduce the incidence of out-of-wedlock pregnancies; and (4) encourage the formation and maintenance of two-parent families.

To date, most attention has focused on moving welfare recipients from cash assistance to work in order to lower families' dependence on public support. But this push toward work lends even greater importance to a second focus of the law, provision of public support for child care. As stated in the recently released TANF regulations, in implementing welfare reform, states should carefully provide for and protect "needy and vulnerable children." Caring for low-income children while their parents are working is certainly one aspect of this duty. To this end, an important part of PRWORA provides additional funding to states for child-care 
services for low-income families and to improve the quality and supply of child care. In addition, PRWORA attempts to simplify the complex child-care system by combining programs and provides states some increased flexibility in setting policy.

The passage of welfare reform has led to changes in many social programs, and the new system is still evolving. However, sufficient time has now passed to allow examination of some of the major changes states have made in response to welfare reform. In this paper, we focus on two areas of change: the new cash-assistance program known as Temporary Aid for Needy Families (TANF - Title I of PRWORA), which replaced Aid to Families with Dependent Children (AFDC), and the program that provides low-income families with subsidies to purchase care for their children, the Child Care Development Fund (CCDF-Title VI of PRWORA). The intent of this paper is threefold: to provide an overview description and assessment of the changes PRWORA made to these two social welfare programs, to discuss how these reforms changed incentives for states and families, and to provide a preliminary assessment of the impact of PRWORA on state and local governments and low-income families with children.

In the next section of the paper, we consider the changed incentive system faced by state and local governments. We first review changes in the cash-assistance program. We provide an overview of TANF and assess the ways in which changes altered the incentives facing states, particularly incentives to increase the number of TANF families that work. We also describe the way in which state and local governments have, to date, responded to the changed incentives they face.

We next provide an overview of the changes in child-care programs. Our discussion of child-care programs is more detailed because the nature of these programs is less well known. We proceed to discuss changes in incentives for states under the CCDF and describe how state and local child-care programs have evolved since the passage of PRWORA.

In the third section of the paper, we examine how some of the changes in state policies affect family incentives to work and to receive cash assistance and provide a preliminary assessment of the impact of these changes on the employment and earnings of lowincome families with children. The fourth section describes the employment and child-care arrangements of low-income families who have recently left welfare, using data from the National Survey of America's Families. These data provide a picture of family outcomes in the early stages after welfare reform. The final section of the paper contains our conclusions. 


\section{CHANGES IN STATE INCENTIVES UNDER PRWORA}

PRWORA changed incentives for states and families, its major changes being in income-support and child-care policies for families with children. In this section, we first describe the changes made to cash assistance, focusing on the structure of funding and program rules that encourage work and limit dependency among welfare recipients. We describe how these changes altered the incentives faced by state governments and the way in which states have altered their cash-assistance policies since the passage of PRWORA. We then describe the changes in state child-care programs, including the incentives inherent in these programs and how they have changed since PRWORA.

\subsection{Cash-Assistance Policies}

This subsection reviews the changes to cash-assistance policies under PRWORA, focusing on the changes in funding mechanisms and policy changes and state responses that encourage work and reduce dependency. We start with a brief history of cash-assistance programs.

\subsubsection{A Short History of Cash-Assistance Programs The first federal} cash-assistance program for families with children was Aid to Dependent Children, established by the Social Security Act of 1935 and renamed Aid to Families with Dependent Children (AFDC) in 1962. AFDC provided cash assistance for needy children who have been deprived of parental support or care because their father or mother was absent from the home, incapacitated, deceased, or unemployed. AFDC was state-administered and funded jointly by the federal government and state governments. The program was an entitlement, that is, all families that met certain categorical and financial requirements were entitled to benefits.

States could not determine who was eligible for AFDC, but could set benefit levels. The level of AFDC benefits varied widely across states. In early 1996, monthly benefits for a single-parent family with two children and no income ranged from $\$ 120$ in Mississippi to \$597 in Vermont, even higher in Alaska and Hawaii.

The number of cash-assistance recipients fluctuated broadly between the 1960s and the 1990s. As can be seen in Figure 1, approximately 3 million people received benefits in 1960, less than 2 percent of the U.S. population. Between the late 1960s and early 1970s, the number of recipients more than tripled. The AFDC rolls experienced a second growth spurt beginning in 1990. The rolls peaked in 1994 with a total of 14.2 


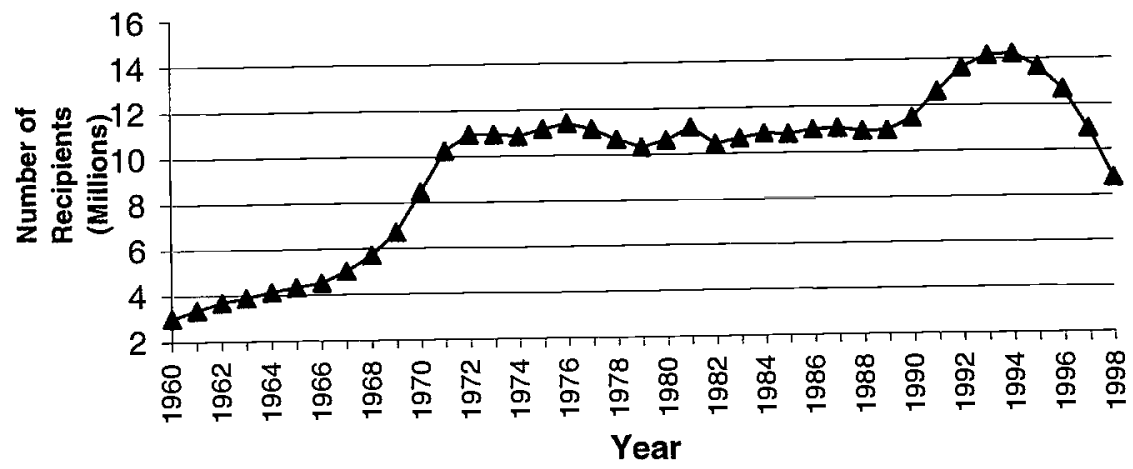

FIGURE 1. Number of Welfare Recipients, 1960-1998

million recipients (51/2 percent of the population) and have been declining steadily since then. In March 1999, there were 7.3 million recipients of TANF, a 48-percent decline in the number of recipients of cash assistance since the peak in 1994.

Beginning in the late 1960s, a series of reforms to the AFDC program sought to promote work and to limit long-term dependence among recipient families. An early attempt was the Work Incentive (WIN) program created in 1967, followed by the $1990 \mathrm{Job}$ Opportunities and Basic Skills (JOBS) program.

The 1996 welfare reform embodied in PRWORA was much more comprehensive than previous reform efforts. Under PRWORA, a new program, Temporary Assistance for Needy Families (TANF), replaced the old AFDC cash-assistance program. States were given substantially more latitude in designing their cash-assistance programs within broader federal guidelines.

As a precursor to federal reform, many states had made changes in the structure of their AFDC programs through waivers-federal agreements to allow states to change specific aspects of their programs (Zedlewski, Holcomb, and Duke, 1998). Through waiver activity, states initiated and implemented many of the changes that were eventually included in PRWORA. ${ }^{1}$ For some states, PRWORA imposed new requirements that would substantially change their programs. For other

1 After the passage of welfare reform, under certain conditions, states were allowed to continue waiver policies that were not consistent with PRWORA. For example, Massachusetts continues to exempt parents with children below age six from work requirements under a waiver it obtained prior to welfare reform. 
states, it reinforced aspects of policies they were already implementing or wanted to implement.

The shape and form of state TANF programs are still evolving. Some states have substantially transformed their systems, while others have made relatively few changes beyond federal requirements. ${ }^{2}$

\subsubsection{Funding Changes: From Matching Funds to Block Grants Changes} in the structure and amount of funding for cash assistance and increased state autonomy over how to use welfare funds have changed states' incentives. One of the major changes for states in the PRWORA legislation was moving from a state-federal matching system for funding cash assistance to a federal block grant to states.

The annual level of the TANF block grant remains basically fixed for the duration of PRWORA, until 2002. ${ }^{3}$ The amount each state receives is based on the level of federal contributions to the state for the AFDC, JOBS, and Emergency Assistance programs in 1994.

Under AFDC, federal funding for the cash-assistance program required a state match. The proportion of funding that states were required to provide was inversely related to state per capita income. In 1996, the last year of the AFDC program, high-income states were required to provide $\$ .50$ for each $\$ 1$ of federal funding, and low-income states matched at a lower rate. For example, Mississippi was only required to provide $\$ .22$ for each $\$ 1$ of federal funding in 1996.

Conceptually, the change to a block grant introduces an incentive for states to decrease their program spending, since each additional dollar of program expenditure beyond the federal block-grant level is now more costly. In the block-grant system of funding, the marginal additional dollar of increased funding above the level of the federal grant must come entirely from the state. Under a pure block grant, with no other funding restrictions, states could potentially choose to spend less than or exactly the federal block grant on cash assistance, and provide no state funds.

To counter the incentive toward decreased spending, PRWORA requires that states maintain their spending for welfare programs at 80 percent of their 1994 spending levels, with a reduction to 75 percent if states meet other work-participation requirements. The block grant to

\footnotetext{
${ }^{2}$ Our discussion below reflects the most up-to-date information available during the summer of 1999, generally data for 1997 and 1998.

${ }^{3}$ The exception is that about 20 states will receive 2.5 -percent increases in funds each fiscal year because of high population growth or low 1994 AFDC benefit levels, 35 percent or less of the national average.
} 
the states is reduced $\$ 1$ for every $\$ 1$ by which the state falls short of this maintenance of effort (MOE) requirement.

Given that block-grant funding was set relative to a prior year and caseloads declined considerably between 1994 and 1997, most states got an initial windfall increase in funding over what their matching funds would have been under AFDC. The U.S. General Accounting Office (1998a) estimated that the TANF block grant for 45 states exceeded the federal funding level they would have received under the AFDC program.

FY 1998 was the first full year that all states implemented TANF. State reports of expenditures indicate that all states met the MOE requirement needed to draw down all federal funds available to them under the TANF block grant. Most states reported (although not required to do so) that their spending exceeded their MOE requirement (Administration for Children and Families, 1999b).

Under PRWORA, states have substantially more freedom in deciding how they spend funds. States may spend the block grant "in any manner that is reasonably calculated to accomplish the purpose" of PRWORA. Large caseload declines have presented the possibility for states to increase per-case spending even without increasing state expenditures. States can use their TANF block grants for cash assistance and/or for a broad array of other purposes (e.g., child-care and transportation assistance) designed to benefit needy families with children. The greater freedom in the use of funds may lead to greater spending as states are able to design programs that are more attuned to their own preferences.

PRWORA also removed the entitlement to cash assistance for lowincome families with children. Since federal TANF program funding will not grow with each new eligible family, states may decide not to serve some families who meet eligibility requirements. This means that during a recession the TANF program, unless altered, will not see the increase in federal expenditures with new recipients that would have occurred under the AFDC entitlement program.

In the current strong economy and with declining caseloads, the fixed block grant through 2002 provides incentives for states to reserve part of their initial windfall for the next economic downturn or other unexpected events. These reserved funds, allowed under PRWORA, are sometimes referred to as "rainy day funds." The law puts no limits on the amount of funds that can be reserved from one year to the next. ${ }^{4}$

4 The final TANF regulations indicate that funds carried over from previous years can only be spent on certain activities defined as "assistance." For further discussion of this potential limitation see Schott, et al. (1999). 
As of the end of the first quarter of FY 1999, states' cumulative unobligated balances of TANF block-grant funds were $\$ 4.2$ billion, or 12 percent of the total federal TANF funds awarded the states since implementation of the TANF program (Administration for Children and Families, 1999a). Concerns have been raised that these unused funds may be viewed by Congress as a reason to cut future levels of the block grant or as a source of funds for other desired spending. Some in Congress have suggested that states should return unused TANF funds to the federal government to be used on program expansion and new programs, but no action has been taken. The House has recently proposed cutting the amount of the TANF block grant.

\subsubsection{Program Structure: Flexibility and Requirements PRWORA gave} states broad flexibility to create new transitional assistance programs for families with children. At the same time it put in place some specific requirements that states must follow or face financial penalties. The law made many specific changes to cash assistance. We focus here on the changes that are likely to have the greatest impact on work. ${ }^{5}$

The major changes in TANF that were intended to decrease dependency and promote work under PRWORA are the federal work participation requirements and the limits on length of time families can receive federally-funded benefits. The financial penalties associated with not meeting work requirements increase states' incentives to move families receiving transitional assistance into work and work activities as rapidly as possible.

New TANF Requirements Each state must meet federally-set work participation requirements. The overall work participation requirement for all families started at 25 percent of the caseload in FY 1997, rose to 40 percent of the caseload in FY 2000, and will rise to 50 percent of the caseload in FY 2002. The minimum participation rate for two-parent families was 75 percent in FY 1997 and increased to 90 percent in FY 1999. States may exempt single parents with children under age one from the work requirement. ${ }^{6}$ PRWORA also allows a reduction of the

${ }^{5}$ Some of the changes we do not discuss here include increases in eligibility for two-parent families, caps on benefits for additional children, changes in how much child support can be passed on to families, reduced eligibility for immigrants, and additional requirements for teen parents.

${ }^{6}$ States are allowed to calculate these percentages out of the population with children over age one, if they choose to exempt these parents from work requirements. Forty-five states have exempted families with a child under age one or a younger age cutoff. Other than this group, regardless of state policy on exempting persons from work requirements, all families with an adult beneficiary are included. 
work participation requirement by the amount of a state's caseload decline since 1995. Caseload reduction has been so great that the effective work participation requirements for many states are relatively low. For example, Indiana had an adjusted requirement of 5 percent and Wiscon$\sin 8$ percent in 1997.

PRWORA also requires nonexempt recipients to participate in work or work activities within 24 months of initial benefit receipt. Most states have adopted a requirement of participation by 24 months or whenever the recipient is determined to be ready to work, whichever is earlier. Several states have set shorter periods; for example, Wisconsin requires immediate participation, and Virginia requires participation within 90 days.

The law also defines the set of work activities that can count toward the participation requirements. This set is more limited than under past programs, putting greater emphasis on work and short-term job readiness activities as opposed to longer-term training and education. For example, a maximum of 12 months of vocational education can be counted.

One of the major changes in the new law is the limit on the time recipients can receive benefits. Adult recipients can receive at most five years of benefits from TANF federal funds over their lifetime. States have the option of setting lifetime limits of less than five years. States can make payments beyond five years using their own funds. States can also give exemptions to the time limit for up to 20 percent of their caseload.

As of the end of 1997, twenty-one states had time limits of less than 60 months for at least some recipients (Gallagher et al., 1998). In some of these states, families reaching the shorter time limit lose only a portion of their benefits. On the other hand, two states, Michigan and Vermont, have no benefit time limit, pledging to use state funds to extend benefits for those who continue to be eligible after 60 months. California plans to continue payments to children, but not to adult family members, after the family has received 60 months of benefits.

States have varied criteria for exempting families from the time limit (Bloom, 1999). Some exemptions are determined at eligibility and keep "the clock from ticking"; others are determined at the time a family hits the time limit. Some criteria are clear-cut, such as an adult being over a certain age limit, and others are more subjective, such as if a family "played by the rules" and still has a very low level of income.

States have been reasonably successful in moving welfare recipients into work activities, at least in comparison with the federal mandates. For FY 1997, all states met their all-family work participation requirement. In part this was due to states' credits for the caseload reductions. 
Many states, however, had trouble meeting the two-parent participation requirement.

State Program Changes to Increase Work In addition to responding to the federal work requirements and time limits in PRWORA, states have used their new flexibility to structure other aspects of their welfare programs to encourage work and responsibility and decrease dependency. These changes include new financial incentives to work as well as changes in the structure and emphasis of program services.

Most states have simplified the treatment of earnings, compared to AFDC rules, and have altered their earnings disregards to encourage work. While AFDC required states to disregard a portion of earned income, the amount was limited and had a steep phase-out period. Many states have increased the amount of earnings that can be disregarded or have eliminated the phase-out period. For example, California now disregards $\$ 225$ of earnings and 50 percent of the remainder for an unlimited number of months. Connecticut disregards all earnings below poverty, with a family remaining eligible as long as earnings are below poverty. These changes reflect state priorities to "make work pay" as well as help to ensure that states meet federally imposed work requirements.

In addition to more generous earnings disregards, many states integrated a system of work supports into their TANF programs. Work supports include subsidies for work expenses. This decreases the cost of work, at least over the term of the subsidy, increasing the financial returns to work. Work subsidies for recipients include child care, health insurance, transportation costs, uniforms and tools, and even licensing.

State Changes in Program Structure and Emphasis In addition to increasing financial incentives to work, many states have changed the structure of their programs to emphasize and require work. Nathan and Gais (1999) argue that PRWORA provided a strong signal that the federal government was permanently changing the nature of public assistance, encouraging states to restructure programs and move toward a more employment-focused system. ${ }^{7}$

Nearly every state has instituted "social contracts" or other personalresponsibility agreements in which recipients agree to specific steps toward self-sufficiency. Many states are enforcing these agreements, sanctioning people who fail to sign or live up to their agreements. While

${ }^{7}$ See Quint et al. (1999) for a discussion of the implementation of welfare reform in large cities, and Nathan and Gais (1999) for a study of the implementation of welfare reform in 20 states. 
the AFDC-JOBS program had sanctions for not following certain requirements, under TANF many states have chosen to expand their use of sanctions. States are also making sanctions more severe, imposing larger benefit reductions for longer periods more quickly. Fourteen states, including Florida and Ohio, now have full benefit reduction, meaning total loss of benefits, for an initial failure to comply with work-activities requirements (Gallagher et al., 1998).

In addition, many states are putting emphasis on diverting potential recipients from the welfare rolls. For the most part, diversion programs use lump-sum payments either in cash to the family or to a third party (for example, for rent, utilities, or car repair). By accepting the upfront diversion payment, the family generally agrees not to reapply for cash assistance for a specified period of time: e.g., receipt of a diversion payment equal to 3 months of benefits requires the family's agreement not to reapply for benefits for 3 months. ${ }^{8}$

In addition to diversion payments, some states have implemented mandatory applicant job search as a condition of TANF eligibility to encourage work-ready applicants to find jobs rather than receive transitional assistance.

Almost all states have moved to work-first models for their welfare programs, requiring recipients to move quickly into available jobs. ${ }^{9}$ One aspect of moving away from writing assistance checks and moving towards a work-focused system is that states are using more of their welfare funding to provide services. Most state welfare programs now provide more work-related services (e.g., work preparation, job search, job placement) and provide these services to a greater proportion of recipients than under JOBS.

Based on state-reported expenditure data for TANF and the Child Care Development Fund (CCDF), states are spending less on direct cash assistance while investing more resources in supportive services (National Association of State Budget Officers, 1998). On average states used 65 percent of their MOE funds and 69 percent of their federal TANF funds for cash assistance. However, the range of expenditures on cash assistance was wide (Administration for Children and Families, 1999b).

\subsection{Child-Care Policy}

PRWORA changed federal child-care policy in several important ways. The law increased federal funding for child care substantially. In addition, it eliminated the requirement that states spend their own funds on child

${ }^{8}$ For in-depth discussion of these policies see Maloy et al. (1998).

${ }^{9}$ For more information about work-first programs see Holcomb et al. (1998). 
care, but gave states an incentive to maintain and increase their funding. PRWORA also gave states the option of transferring up to 30 percent of their TANF grant to the Child Care Development Fund, thereby increasing the pool of funds available for child care. The legislation eliminated the federal entitlement to child care for families on and transitioning off cash assistance, but provided states with an incentive to continue to give welfare families priority for the receipt of subsidy funds. The law gave states some additional flexibility in setting policies regarding eligibility, the amount paid to providers, and families' share of child-care costs. States also have more latitude in the use of funds to improve the quality of child care and to increase the supply of care.

\subsubsection{A Short History of Federal Child-Care Programs As with cash} assistance, the federal government's role in child care began with the New Deal, which created federally funded nursery schools for poor children. The schools were designed primarily to create jobs for unemployed teachers, nurses, and others to provide a healthy environment for children in poverty. With the advent of World War II, many of these schools were continued and expanded to provide care for the children of "Rosie the Riveter." Under the Lanham Act, child care was provided for an estimated 550,000 to 600,000 children. The Lanham Act terminated in 1946.

After 1946, the federal government largely withdrew from the childcare arena until the 1960s, although some states, like California, continued to provide publicly funded child care. As part of the war on poverty, Head Start was begun in 1965 to provide comprehensive services to poor 3- to 5-year-olds on a part-day, part-year basis.

The 1988 Family Support Act expanded the federal government's role in child care as part of a larger effort to encourage welfare recipients to find employment. The act created two federal child-care programs: the AFDC-JOBS Child Care program and the Transitional Child Care Program (TCC). Both programs were entitlements guaranteeing assistance to all eligible families currently on public assistance that were working or in other approved activities (e.g., participating in the JOBS program). The TCC program provided subsidies to working former AFDC recipients for a year after they left the AFDC rolls.

The 1990 Omnibus Reconciliation Act made child-care subsidies available to families who did not receive cash assistance under the At-Risk Child Care Program and the Child Care and Development Block Grant (CCDBG). The At-Risk program targeted families who were at risk of going on AFDC, which in practice included most low-income families. Collectively, the At-Risk Child Care Program, the TCC program, and the 
AFDC-JOBS child-care programs are referred to as Title IV-A child-care programs because they were created under Title IV-A of the Social Security Act (Committee on Ways and Means, 1996). The CCDBG was designed to help states provide child care to low-income families and to fund activities to improve the quality and supply of child care for all families. No family was entitled to receive child-care subsidies under the At-Risk or the CCDBG child-care programs.

The 1996 welfare reform legislation consolidated the four federal lowincome child-care programs into a single block grant, the CCDF. ${ }^{10}$ The goal of the program is to fund child-care services (including subsidies) for low-income families, "as well as activities intended to improve the overall quality and supply of child care for families in general" (Committee on Ways and Means, 1998). The creation of the CCDF was intended to simplify the administration of child-care subsidies by reducing the complexity of regulations governing them, and to give states additional flexibility in allocating their funds. Welfare families and families transitioning off welfare are not entitled to receive assistance under the CCDF.

\subsubsection{Changes in Funding for Child Care The creation of the CCDF} resulted in three important changes in the way that child care is funded. First, it substantially increased the level of federal funding for child care. Second, while CCDF consolidated four child-care funding streams, it created a complicated system that mixes features of block grants and a matching-fund system. The system also has MOE requirements. Under the CCDF, states are not required to spend their own funds on child care. However, the funding system provides incentives for states to maintain and increase their child-care spending. Third, it permitted states to spend TANF dollars on child care.

Increase in Child-Care Funding Perhaps the most important change in child-care funding resulting from PRWORA was the increase in federal funding. The additional funds allowed states to serve more lowincome families and/or to more generously fund the families served. The total federal funding to states under CCDF was $\$ 2.56$ billion in 1997 and $\$ 2.80$ billion in 1998 (U.S. Department of Health and Human Services, 1999). The 1997 funding level represented a 27-percent increase over the funding level that would have occurred under the pre-PRWORA programs (Long, Kirby, Kurka, and Waters, 1998).

10 To avoid confusion, this paper will refer to the new low-income child-care funding stream created under the 1996 welfare reform legislation as the Child Care Development Fund (CCDF). The CCDF was created as part of the reauthorization of the Child Care and Development Block Grant. 
Changes in Program Funding Rules Like AFDC, the AFDC-JOBS and TCC programs were funded by a state-federal matching system. The federal government matched each state dollar spent at the Medicaid matching rate. The At-Risk child-care program had the same statefederal matching system as the AFDC-JOBS and TCC programs, but the amount of the funds the state could receive from the federal government was capped. Only one of the four pre-PRWORA federal child-care programs did not require states to put up matching funds-the Child Care and Development Block Grant. Under CCDBG, states received a block grant. The amount of the grant depended on the proportion of children under age five in the state, the number of children receiving free or reduced-price lunches, and state per capita income.

Like CCDBG, CCDF guarantees states a minimal level of child-care funding regardless of how much the states spend from their own coffers. However, like the Title IV-A child-care programs, CCDF provides an incentive for states to maintain or increase their child-care funding. Indeed, states have more incentives to increase child-care spending under CCDF than they did under the pre-PRWORA system.

Under CCDF, federal funding for child-care subsidies is consolidated. However, the consolidated fund has three distinct components. Each component is governed by a different set of rules. To be specific, under CCDF, a state's funding for child-care subsidies has three separate components, referred to as (1) mandatory funds, (2) matching funds, and (3) discretionary funds. ${ }^{11}$

States are entitled to receive mandatory funds, which are also known as guaranteed funds, regardless of how much state money they spend on child care. States need only meet their MOE requirements under TANF to be eligible for these funds. Each state's amount of mandatory funds is based on the state's federal allocation under the three Title IV-A programs. ${ }^{12}$ The mandatory funds are not subject to the annual government appropriation process. The federal government allocated approximately $\$ 1.2$ billion in mandatory CCDF funds to states for FY 1997 through FY 2000.

The rules governing matching funds gives states an incentive to maintain or increase their child-care spending. To receive matching funds, states must meet both matching and MOE requirements. They also must have spent all of their mandatory federal funds. To meet their MOE

${ }^{11}$ For the interested reader, Greenberg (1996) provides details of CCDF funding mechanisms, and Committee on Ways and Means (1998) provides a useful summary.

12 The state's allocation is equal to the federal allocation in 1994, the allocation in 1995, or the average of the 1992-1994 allocations, whichever is highest. 
requirements, states must maintain at least their level of funding under Title IV-A programs. States spent $\$ 908$ million to meet their maintenance of effort requirements in FY 1998.

Each dollar that a state spends beyond its MOE requirement is matched at the state's 1995 Medicaid matching rate. When drawing down matching funds, the marginal cost of each additional state dollar spent on child care varies from $\$ .21$ for Mississippi to $\$ .50$ in relatively high-income states like California. The maximum amount of matching funds available to a state depends on the state's share of the total number of children under 13 in the U.S. In FY 1998, states provided \$724 million and the federal government $\$ 551$ million under the matchingfund program (Administration for Children and Families, 1999c).

Finally, states may receive discretionary funding under CCDF. The level of these funds varies from year to year at Congress's discretion, and is subject to the annual appropriation process. A state's share of discretionary funds is determined using the same funding formula as for CCDBG (see above). Discretionary spending has no matching or MOE requirements. Congress may also earmark particular parts of the discretionary funds for certain activities. In FY 1998, Congress allocated $\$ 975$ million to the discretionary part of the CCDF. Fifty million of these funds was earmarked for improving the quality of infant and toddler care, and $\$ 18.6$ million was earmarked for improving school-aged child care and for resource and referral services.

Spending TANF Funds on Child Care PRWORA makes another important change to the child-care funding process: it allows states to spend up to 30 percent of their TANF block grant on child care (Greenberg and Savner, 1998). States now have the flexibility to focus more of their TANF dollars on employed parents who are former recipients of cash assistance or on low-income families that have never received TANF.

States can spend TANF dollars on child care in two different ways. First, they can transfer the funds to the CCDF. The transferred funds are subject to CCDF regulations. ${ }^{13}$ Second, states can fund child care directly from the TANF program. Child-care funds coming directly through TANF are not necessarily subject to CCDF regulations (Committee on Ways and Means, 1998).

${ }_{13}$ In addition, states were allowed to meet their TANF maintenance-of-effort requirements by counting funds spent on state early-childhood education and care programs. A handful of states (Arizona, California, Iowa, and Wyoming) did so (Department of Health and Human Services, 1998a). Such state programs could fulfill the MOE requirements if they did not separately qualify for a federal match in a different program (Committee on Ways and Means, 1998). For example, states could not count child-care funds towards both the MOE requirements for TANF and the MOE or matching requirements for CCDF. 
Receiving child-care funding directly through TANF and not through CCDF can have an important implication for unemployed parents. Parents who are not employed are subject to TANF time limits when receiving child-care assistance directly through the TANF block grant, but not when receiving child care under CCDF (Greenberg and Savner, 1998). ${ }^{14}$

States' Responses States have responded to federal incentives by increasing or maintaining their funding for child-care subsidies. As noted in the TANF section, all states met their TANF MOE requirement in 1998, and thus all states qualified for their full share of mandatory CCDF funding. In 1998, all 50 states and the District of Columbia drew down all of their CCDF matching funds by meeting their MOE and matching requirements.

Overall, state spending on child care has grown substantially since PRWORA. Expenditures of state dollars for child care grew by an average of 24 percent a year from 1996 through 1998. However, changes in state expenditures varied widely. For example, the National Association of State Budget Officers (NASBO) estimates that Nevada's expenditures of state funds on child care increased from $\$ 0.5$ million in 1996 to $\$ 5.7$ million in 1998, while Nebraska's declined from \$12.7 million in 1996 to $\$ 9.4$ million in 1998. Available budget numbers suggest that most, but not all, states have a strong commitment to funding child care (National Association of State Budget Officers, 1998).

As a result of the increases in funding, the number of children receiving child-care subsidies has increased markedly since PRWORA at the same time that TANF caseloads have declined. In a study of seven states, GAO (U.S. General Accounting Office, 1998a) found that $17 \%$ more children were receiving child-care subsidies in 1997 than in 1996.

The CCDF matching and MOE requirements are just one of the reasons why states have increased their child-care funding. There are at least four other important reasons. First, states have an incentive and a desire to increase work and work-related activities among TANF recipients, and child care is an important supportive service to help recipients find and keep jobs. Second, some states want to increase funding for low-income working families who were not on welfare, perhaps out of a desire to treat welfare and nonwelfare families more equitably. Third, some state legislatures' interest in child care has been sparked by research that shows that the first three years of life are crucial in children's

${ }^{14}$ States can also transfer up to 10 percent of their TANF block grant to the Social Services Block Grant (SSBG), which states may use to fund child care. The total of TANF transfers to both CCDF and SSBG cannot exceed 30 percent. In 2001, the maximum amount that states can transfer to SSBG will decrease to 4.25 percent (Greenberg and Savner, 1998). 
brain development. Finally, the increase in federal funds available for child care under both CCDF and TANF created an income effect.

The majority of states have chosen to use a portion of their TANF block grant for child care. In 1998, 23 states and the District of Columbia transferred funds from their TANF block grant to their CCDF block grant. In addition, 12 states spent TANF funds directly on child care. Seven states (California, Florida, Michigan, North Carolina, Oklahoma, Vermont, and Virginia) did both. Nationwide, 2.6 percent of TANF funds were transferred to CCDF and 4.6 percent were spent directly on child care.

\subsubsection{Changes in Eligibility Rules for Child Care Under PRWORA,} states have substantially more freedom to decide which low-income families receive child-care subsidies. As noted earlier, states are no longer required to guarantee subsidies to families on or transitioning off of cash assistance. States are allowed, but not required, to serve families with incomes up to 85 percent of state median income (SMI). This represents an increase from the 75 percent of SMI allowed under CCDBG. However, most states set income-eligibility limits under the maximum level allowed by the federal government both under CCDBG and CCDF.

As under CCDBG, states can choose to allocate child-care funds to any family involved in work activities with a child under 13 that has incomes below the state-determined eligibility level. States continue to have some discretion in determining who is eligible for CCDF subsidies, because they can determine what qualifies as a work activity (Committee on Ways and Means, 1996, 1998). For example, some states count attending high school, two-year college, and/or four-year colleges as a work activity, while others do not. There is some concern that state policies that do not allow college students to receive child-care subsidies limit the ability of parents to increase their earnings. States can also use CCDF funds to provide child care for children in need of protective services because of risk of abuse or neglect, regardless of family income.

States' Responses States' responses to their new freedom to serve families between 75 percent and 85 percent of SMI varied. As reflected in their plans for 1997-1999,15 nine states, including Alaska, Connecticut, Louisiana, Mississippi, and Oregon, indicated that they planned to avail

15 The federal government requires states to submit child-care plans that outline states policy intentions for the upcoming two fiscal years to the Administration for Children and Families. The first state plans under CCDF were for the period October 1, 1997 through September 30, 1999. While these plans are not binding, they do give a general sense of states' intentions. 
themselves of the new flexibility under $\mathrm{CCDF}$ and raise income eligibility to 85 percent of SMI. According to the plans, states set income eligibility for child-care services from 42 percent of SMI (Missouri and Wyoming) to 85 percent of SMI.

The diversity of state changes in income eligibility under CCDF is illustrated in Table 1. As can be seen in this table, 10 of the 13 Assessing the New Federalism (ANF) states raised their income-eligibility limits under PRWORA. ${ }^{16}$ Two states (Alabama and Wisconsin) lowered their income-eligibility limits. Four states (Colorado, Mississippi, Texas, and Washington) raised their income-eligibility limits substantially enough that the limit both as a percentage of state median income (SMI) and as a percentage of the federal poverty level (FPL) increased (Long, Kirby, Kurka, and Waters, 1998). On average, states raised their income eligibility limits by a little over $\$ 130$, an amount large enough to preserve the relationship between the limit and the FPL.

Interpretation of income-eligibility limits is not straightforward. Some states set relatively high limits, but do not have funds available to serve all families that qualify for assistance. For example, Mississippi's increase in income eligibility did not benefit many eligible low-income families, because funding for CCDF did not allow the state to serve all eligible families that applied for assistance. Other states set lower incomeeligibility limits, but serve all eligible families (e.g., Wisconsin and Illinois after PRWORA). States sometimes lower their income-eligibility limits to get rid of waiting lists.

\subsubsection{Whom to Serve? How States Allocate Child-Care Resources Under} the CCDF, states have broad flexibility in deciding which low-income families receive child-care subsidies. States may choose to provide a guarantee of subsidies to eligible low-income families, or they may give priority for subsidies to certain groups of the eligible population.

PRWORA requires that states give the highest priority for child-care subsidies to very low-income families and to children with special needs. However, states decide what level of income constitutes very low income and what constitutes a special need (Department of Health and Human Services, 1998a).

The legislation provides incentives for states to continue to give priority for child care to families on or transitioning off cash assistance. TANF regulations indicate that states cannot sanction parents of children under age 6 who cannot find suitable child care (Greenberg and Savner, 1998).

16 These data are from in-depth case studies of welfare and child-care programs conducted in 13 states in 1997 as part of the Urban Institute's Assessing the New Federalism project. 


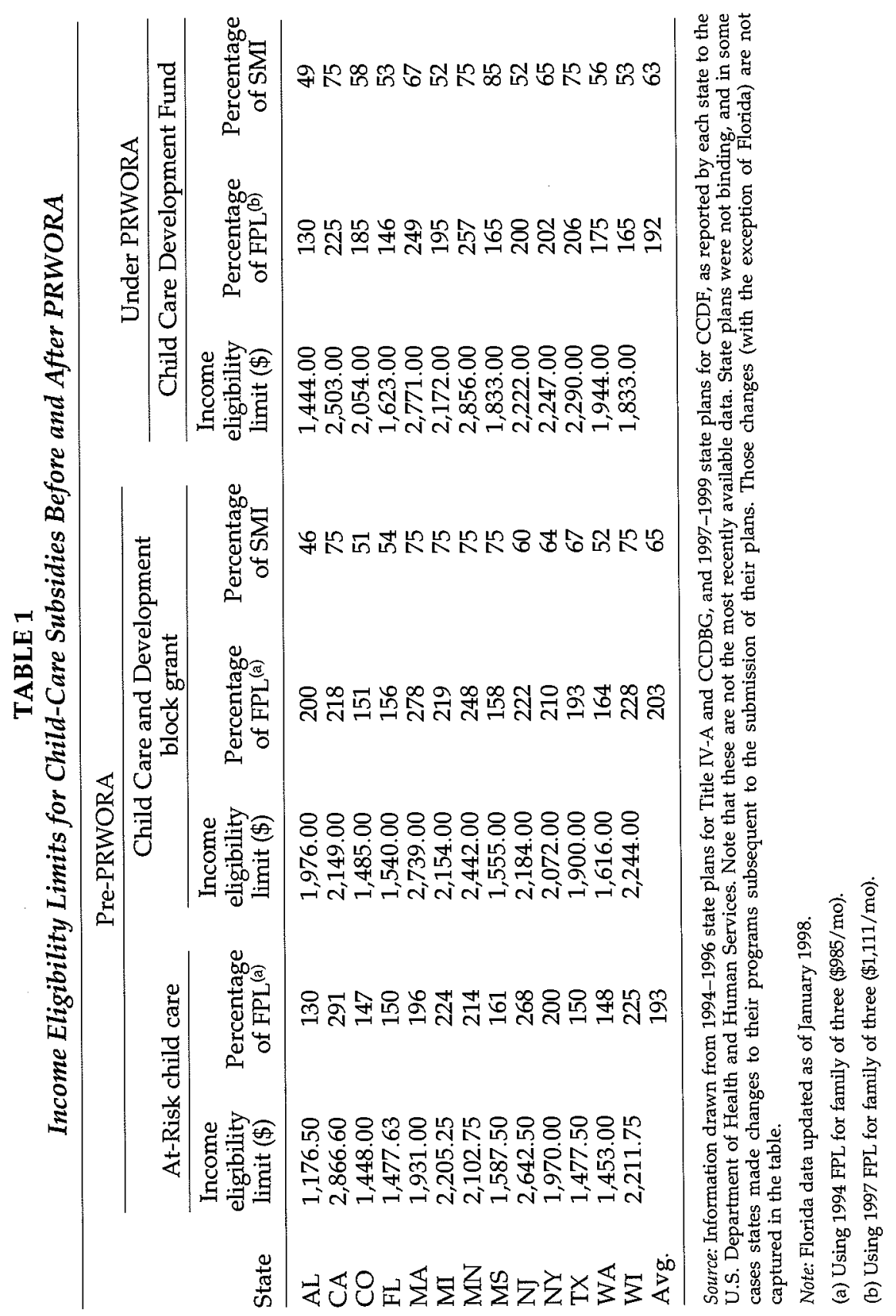


Families newly applying for TANF subsidies are also often given priority for child-care subsidies in order to keep them from entering the TANF rolls. This priority for subsidies is an important element in the diversion programs discussed in the previous section.

There is some empirical evidence that providing child-care subsidies increases the number of TANF recipients who work and help other working-poor families to remain independent. Chipty, Witte, and Queralt (1999), Lemke et al. (1999), and Queralt, Witte, and Griesinger (1999) find that families on cash assistance have significantly higher probabilities of work and significantly higher earnings when child-care subsidies are more generously funded. Witte, Queralt, Chipty and Griesinger (1999) report that both former recipients of cash assistance and other low-income families eligible for child-care subsidies have higher earnings when funding for child-care subsidies is more generous.

States' Responses States have responded in a variety of ways to their new flexibility in deciding which families receive child-care subsidies. According to state plans, all but four states have established definitions of very low income that are below their standard income-eligibility level. Definitions of very low income ranged from around $\$ 1,500$ below the standard income-eligibility limit (for Georgia) to almost $\$ 26,000$ below that limit (North Dakota). Three states (Alabama, Florida, and North Carolina) specifically indicated that very low income was equal to their standard income-eligibility level (Administration for Children and Families, 1998a).

In practice, some states that defined very low income as below their standard income-eligibility limit do not give very low-income families priority, and some states that have definitions of very low income equal to their standard income-eligibility limit give priority to lower income groups.

Consistent with incentives under PRWORA, most states give priority to families with some connection to the TANF system. In 1997, most ANF states gave welfare recipients highest priority for receiving childcare subsidies. Families transitioning off welfare were often given second priority. At least four ANF states (California, Florida, New Jersey, and Texas) have extended the period of child-care subsidy eligibility beyond the 12-month period mandated under the TCC program (Long, Kirby, Kurka, and Waters, 1998; Witte, Queralt, Chipty and Griesinger, 1999). State child-care administrators in some of the ANF states said that they were hesitant to expand funding beyond the welfare population because they were concerned about an increase in demand for child care among families on welfare and transitioning off welfare, espe- 
cially families with very young children (Long (1999) and Long and Clark, (1998)).

In many states, low-income working families who are not on cash assistance receive the lowest priority for child-care subsidies. Such families are often placed on waiting lists or simply do not apply for subsidies.

Waiting lists for child-care assistance are quite long in some states. In late 1997, California had over 200,000 low-income families waiting for child-care subsidies. Most of these families were neither current nor former recipients of cash assistance (U.S. General Accounting Office, 1998a). However, the increases in both state and federal child-care funding under PRWORA have allowed many states to decrease their waiting lists. At least four states, Michigan, Oklahoma, Vermont, and Washington, currently have no waiting list for subsidies.

In a more radical departure from the pre-PRWORA system, four states have severed the link between child-care subsidies and cash assistance. These states have guaranteed child-care assistance to all qualifying lowincome families, regardless of welfare status. Three of these states (Colorado, Illinois, and Wisconsin) have decreased income-eligibility limits and increased funding for child care in order to be able to guarantee subsidies. The fourth state, Rhode Island, has chosen an even more dramatic break with pre-PRWORA programs. It both guaranteed comprehensive childcare services to all low-income families and increased its income-eligibility limit. To accommodate these changes, the State nearly tripled its spending for child-care services between SFY 1996 and SFY 2000.

2.2.5 Benefit Levels The two major state policies affecting the level of benefits a family receives from child-care subsidies are: (1) the prices paid by the state to providers for child-care services, called reimbursement rates; and (2) the schedule that lays out the portion of child-care costs that family must pay, called the copayment schedule or the sliding-fee scale. The level of benefits a family receives from child-care subsidies also depends upon their situation (e.g., number of children, age of children, income), the type of child care used, and the state child-care policy. All other things equal, a family with younger children and more children receiving subsidized care will receive higher benefits from a child-care subsidy program. This is true because the price of child care is higher for younger children. Families with children in center care receive higher benefits than families using other types of care. This is true because center care is generally more expensive than family child-care homes (FCCHs), which in turn are generally more expensive than informal care. ${ }^{17}$

17 See Horrace, Schmidt, and Witte (1998) for detailed information on prices of child care. 
State Reimbursement Rates Under CCDBG child-care subsidy programs and now under CCDF programs, states are required to set up programs that maximize parental choice. Parents must be given the option of receiving a certificate (voucher) that can be used to purchase child-care services from either formal (including sectarian) or informal sources (e.g., a relative). In states that contract directly with providers, parents must also be given the option of using a state-contracted provider. Although not well known, under CCDBG the United States has been experimenting with a voucher system for the purchase of child-care services since 1992. Vouchers for elementary and secondary education remain controversial, but vouchers for preschool and after-school care are not only accepted, but also required by the federal government.

For both child-care certificates and contracts with child-care providers, states must decide the amount to pay various types of providers (e.g., inhome, family child-care homes, centers) for various types of services (e.g., care for children of different ages). Under the pre-PRWORA, IV-A child-care programs, states were allowed to pay providers up to the 75 th percentile of the local market rate for the type of care being provided. ${ }^{18}$ States were required to conduct market-rate surveys every two years to determine the 75 th percentiles of market prices. ${ }^{19}$ However, the Administration for Children and Families (ACF) did not enforce this requirement.

Unlike the Title IV-A child-care programs, the CCDBG did not limit state payments to providers to the 75th percentile of market prices for care (Long, Kirby, Kurka, and Waters, 1998). State payments to providers had to be sufficient to ensure "equal access" to child care for eligible children. In practice, most states used the same reimbursement rates for their Title IV-A and CCDBG child-care programs. However, some used the rate flexibility under CCDBG to develop their own policies. ${ }^{20}$

Since PRWORA, requirements for payments to providers mix aspects

18 The 75th percentile emerged as the maximum allowable reimbursement rate as a compromise. Some policymakers felt that the median should be the maximum reimbursement rate allowed, while others felt that poor children should be able to access all care in the community. The latter group argued that poor children need the highest-quality and most comprehensive child care in order to overcome their financial and other home disadvantages.

19 Some states (e.g., Florida, Massachusetts) do not allow providers to charge subsidized parents a fee over and above the state reimbursement rate. In these states, the reimbursement rate sets the upper limit for the price of care that can be chosen. Other states, like Alabama, allow providers to charge families more than the reimbursement rate, so families may have additional fees beyond their copayment.

${ }^{20}$ For example, under its CCDBG program, California reimbursed providers at rates that exceeded the 75th percentile of market prices if the provider charged private clients rates that exceeded the 75th percentile. Under CCDF, the state has expanded this policy to all types of child-care subsidies. 
of the system formally used for the Title IV-A programs with CCDBG's requirement that state reimbursement rates be sufficient to provide equal access to child-care services. Under CCDF regulations, states are required to provide a summary of the facts that they rely on when setting reimbursement rates. The facts supplied must include a description of how adequate rates are to allow subsidized families equal access to child care. The state must demonstrate that subsidized families have equal access using data from a local market-rate survey conducted no earlier than two years prior to the effective date of the state's CCDF plan. Reimbursement rates at or above the 75th percentile of market prices for care are presumed to provide equal access.

State and Federal Responses Since PRWORA, some states and ACF have altered some aspects of their reimbursement-rate policies. Many states now pay different providers different rates depending on the quality or type of care they provide. At least in some areas of the country, ACF is refusing to approve a state's CCDF plan for 1999-2001 if the state has not carried out a market-rate survey during the last two years.

At last count, 17 states had tiered reimbursement rates that paid different rates to different types of providers. For example, Nebraska pays up to the 90th percentile of the market rate for accredited care, and only up to the 75 th percentile for nonaccredited care. ${ }^{21}$ South Carolina has a three-tier reimbursement system that reimburses accredited providers $\$ 10$ more per week than providers that simply meet state licensing standards. Mississippi pays higher rates to providers that meet accreditation standards, have at least one person with an associate or bachelor's degree in ECE or a Child Development Associate (CDA) certificate, and provide at least one of the following services: transportation, sick-child care, weekend care, 24-hour care, holiday care, or expansion of care to full-day services (APWA, 1988). Oklahoma provides a three-tier reimbursement rate with the top rate paid for services in licensed and accredited child-care facilities that employ qualified directors and teachers, provide higher staff compensation levels, and encourage parental involvement (APWA, 1998). See Azer (1999) for details regarding differential reimbursement rates.

Under CCDF, most states continue to rely on market-rate surveys but, at least until this fall, did not conduct market-rate surveys frequently. In their 1997 CCDF plans, $96 \%$ of state CCDF plans indicated that they planned to rely on market-rate surveys to set reimbursement rates. But

21 The most important accrediting body for child care is the National Association for the Education of Young Children (NÁEYC). 
in 1998, only a minority of states (16) based their reimbursement rates on surveys that were less than two years old (Adams, Schulman, and Ebb, 1998). During the last two years, many states have conducted marketrate surveys, and more are currently conducting such surveys in order to obtain ACF's approval of their 1999-2001 CCDF plans. According to their 1997 state plans, 50 percent of states reported that they reimbursed providers at rates up to the 75th percentile of market price for at least some types of care.

Reflecting both old market-rate surveys and reimbursement rates below the 75 th percentile of market prices, reimbursement rates for child care continued to be low in most states under PRWORA. For example, according to states' $1997-1999$ CCDF plans, the maximum reimbursement rate for full-time care in a licensed or registered center for a preschool child (generally 3-5 years old) ranged from $\$ 55$ per week in West Virginia to $\$ 200$ per week in Nevada and Wisconsin. Thirty-four states, including Illinois, Maryland, Ohio, and Oregon, had a maximum reimbursement rates for full-time preschool center care that was below $\$ 100$ per week. The median of state maximum reimbursement rate for fulltime center care for preschoolers was $\$ 83.70$ per week, and the 75 th percentile was $\$ 107$ per week.

As of late 1997, seven of the thirteen ANF states had responded to PRWORA by increasing their reimbursement rates in real terms for centers and family child-care homes, two states held their rates constant for both types of care, two states decreased their rates for both types of care, and two states increased the reimbursement rates for center care and decreased them for family child-care homes (see Table 2).

Family Payments The 1996 welfare reform legislation gave states more uniform guidelines for setting the families' share of child-care costs. The parental program is referred to as the copayment, since the state pays a portion of the cost of care and the family pays the rest.

Prior to PRWORA, the federal government had varying requirements regarding copayments. States were not allowed to charge working AFDC recipients or JOBS participants copayments for child-care subsidies. By way of contrast, states were required to charge copayments to families that received subsidies under the At-Risk and the TCC programs. States were permitted, but not required, to charge copayments to families receiving subsidies under the CCDBG.

Under CCDF, states may charge all families copayments for child care, and the copayments may be set at any level. States may exempt from copayments families with incomes at or below 100 percent of the federal poverty line and families with children needing protective services. All 
TABLE 2

Maximum Reimbursement Before and After PRWORA

\begin{tabular}{|c|c|c|c|c|c|c|}
\hline \multirow[b]{3}{*}{ State } & \multicolumn{6}{|c|}{ Preschoolers } \\
\hline & \multicolumn{3}{|c|}{ Center } & \multicolumn{3}{|c|}{ Family Day Care } \\
\hline & '94-'96 & '97-'99 & Change (\%) & '94-'96 & '97-99 & Change (\%) \\
\hline $\mathrm{AL}$ & $\$ 59.28$ & $\$ 70.00$ & 18.08 & $\$ 56.73$ & $\$ 60.00$ & 5.76 \\
\hline CA & $\$ 97.73$ & $\$ 113.95$ & 16.60 & $\$ 93.53$ & $\$ 102.19$ & 9.26 \\
\hline $\mathrm{CO}$ & $\$ 82.69$ & $\$ 75.34$ & -8.89 & $\$ 72.69$ & $\$ 69.55$ & -4.32 \\
\hline FL & $\$ 68.02$ & $\$ 77.10$ & 13.35 & $\$ 72.61$ & $\$ 79.87$ & 10.00 \\
\hline MA & $\$ 146.87$ & $\$ 135.71$ & -7.60 & $\$ 99.76$ & $\$ 97.03$ & -2.74 \\
\hline $\mathrm{MI}$ & $\$ 65.62$ & $\$ 65.52$ & -0.15 & $\$ 61.72$ & $\$ 61.72$ & 0.00 \\
\hline $\mathrm{MN}$ & $\$ 88.03$ & $\$ 108.06$ & 22.75 & $\$ 71.78$ & $\$ 87.18$ & 21.45 \\
\hline MS & $\$ 60.00$ & $\$ 65.00$ & 8.33 & $\$ 50.00$ & $\$ 35.00$ & -30.00 \\
\hline $\mathrm{NJ}$ & $\$ 196.75$ & $\$ 101.80$ & -48.26 & $\$ 196.75$ & $\$ 76.40$ & -61.17 \\
\hline NY & $\$ 113.19$ & $\$ 130.42$ & 15.22 & $\$ 85.47$ & $\$ 101.44$ & 18.68 \\
\hline $\mathrm{TX}$ & $\$ 67.51$ & $\$ 75.36$ & 11.63 & $\$ 58.15$ & $\$ 64.81$ & 11.45 \\
\hline WA & $\$ 81.04$ & $\$ 36.17$ & -55.37 & $\$ 79.00$ & $\$ 33.67$ & -57.38 \\
\hline WI & $\$ 80.57$ & $\$ 110.68$ & 37.37 & $\$ 80.57$ & $\$ 105.55$ & 31.00 \\
\hline
\end{tabular}

other families are required to contribute to the cost of care (Office of the Inspector General, 1998).

States' Responses States have given varied responses to their additional freedom in deciding which families will be required to make copayments for child care. According to state plans, eleven states (e.g., Arkansas, California, Delaware, South Dakota, and Vermont) plan to require no copayments from families at or below poverty. Eight states (e.g., the District of Columbia, Florida, Illinois, New Jersey, South Carolina, and Washington) have moved towards more uniform copayment schedules across different groups of subsidy recipients, requiring all families to make copayments. ${ }^{22}$ The remaining states plan to require some, but not all, families in poverty to make copayments.

2.2.6 Devolution? Under PRWORA, a number of states have given local government the power to make child-care policy. For example, under its recently passed School Readiness Legislation, Florida has devolved both policymaking and administrative responsibility for all child-care subsidy programs and Early Childhood Education [e.g., Head Start and Pre-Kindergarten (Pre-K) programs] to local boards. These boards will

22 Requiring families whose children are in protective care to make copayments has proven administratively difficult, at least in some states. 
determine eligibility standards, reimbursement rates, and copayment schedules. Texas moved child-care policymaking to the local level on September 1, 1999.

Extensive federal reporting requirements under PRWORA provide a potentially countervailing centralizing force. The reporting requirements have forced states to standardize child-care management information systems across local subsidy management agencies. The required reports provide both the state and the federal government with more complete, timely, and extensive information on how child-care subsidy dollars are spent and what type of families are served. The reports provide the opportunity for increased scrutiny of child-care programs by the state and federal governments. At this point, it is not clear how either the states or the federal government will actually use the information that is being collected.

2.2.7 Administrative Consolidation Prior to PRWORA, child-care policy tended to be fragmented, with child-care assistance for current and former AFDC recipients often separated from child-care assistance for the working poor. PRWORA allowed, but did not require, states to consolidate their cash-assistance and working-poor child-care programs. States may also establish a uniform set of policies for all child-care subsidy programs.

Before 1996, many states had different policies and procedures, and different offices for families receiving cash assistance and working poor families. For example, Long, Kirby, Kurka, and Waters (1998) found that only six of the thirteen ANF states had a single point of entry for all applicants for child care. As families' economic circumstances changed, they often lost one source of funding for subsidies and experienced delays in obtaining subsidies under another program.

In states with fragmented administrative systems, obtaining access to child-care assistance was a difficult and time-consuming process. Families would often have to apply for assistance with multiple agencies and place their names on multiple waiting lists if subsidized care was not available. In Massachusetts, parents could apply for a voucher at their local child-care resource and referral agency or for care at any number of child-care providers with whom the state contracted. The resource and referral agency and the contracted providers all kept separate waiting lists, leading some parents to place their names on multiple lists, hoping for a slot. After a careful study of pre-PRWORA child-care programs, the U.S. General Accounting Office (1994) concluded that "the fragmented nature of the child care funding streams, with entitlements to some 
client categories, time limits on others, and activity limits on still others, produces unintended gaps in services which limit the ability of lowincome families to achieve self-sufficiency."

States' Responses Since PRWORA, some states have consolidated the administration of child-care subsidy programs, while other states have yet to make major changes in their pre-PRWORA child-care assistance programs. In 1997, all four of the ANF states (California, Massachusetts, New Jersey, and Washington) that did not have consolidated central administrations prior to PRWORA planned to consolidate administration of all CCDF funding streams (Long, Kirby, Kurka, and Waters, 1998). Massachusetts administrators credited PRWORA with serving as a catalyst for change within their child-care system. Some of these states still have separate programs for different types of subsidy receipts.

Some states have gone further. For example, both North Carolina and Rhode Island have created state-level councils to coordinate policy and organize support for child-care services (the North Carolina Interagency Coordinating Council and Rhode Island's Children's Cabinet).

Centralizing the administrative functions of programs is one step towards consolidating the fragmented child-care system. It does not, however, guarantee that families will no longer face varying policies and procedures, have different points of entry into the system, or be placed on multiple waiting lists. Some states are making the integration of their child-care systems a priority, going beyond consolidation of program administration. New Jersey reports that since PRWORA it has not only consolidated program administration, but also now presents all families that apply for subsidized care with a single set of policies and procedures. Other states still maintain unconsolidated local systems with varying policies and procedures and multiple points of entry for application.

Welfare reform has also encouraged states to better coordinate their CCDF child-care programs with their Early Childhood Education (ECE) programs. Prior to PRWORA, many ECE programs (e.g., Head Start and Pre-K) served the children of nonworking AFDC recipients for part of the day and part of the year. Part-year, part-day child-care programs are not well suited to the needs of working TANF recipients.

State can better utilize both child-care subsidies and ECE programs if they use child-care subsidies to do such things as extend the hours of care available in ECE programs. CCDF funds are also frequently used to provide care that picks up when ECE programs close. For example, Florida requires its child-care subsidy program to be coordinated with ECE programs and establishes a single administration for all programs. 
As part of administrative consolidation, the state requires a single waiting list for child-care subsidies and ECE programs, and requires the programs to meet specified goals regarding school readiness.

\section{CHANGES IN INCENTIVES FOR FAMILIES AND THEIR RESPONSE}

In addition to providing income support, a goal of welfare policy has long been to influence the behavior of recipients, sometimes in an attempt to undo the disincentives inherent in any welfare program. As noted earlier, when passing PRWORA, Congress explicitly sought to promote job preparedness, employment, and marriage and to discourage out-of-wedlock births. It also gave states the flexibility to develop child-care programs that best suit the needs of children and parents within each state.

In this section we will discuss how recent changes in the structure of welfare programs, under waivers and post-PRWORA, have changed incentives for families in the areas of employment and program participation, and what we know about how families have responded. ${ }^{23}$

\subsection{Incentives Affecting Employment}

Many of the recent changes to welfare are designed to increase incentives to work. At the same time, other policy changes have also increased the financial return to work, providing further work incentives. The changes in policies affecting work can be grouped into three types: financial incentives to work, subsidies for work-related expenses, and mandatory work requirements coupled with benefit sanctions for failure to comply.

3.1.1 Financial Incentives As described earlier, a majority of states have increased financial incentives to work through more generous earnings disregards. These policies allow recipients to keep a greater proportion of their earnings while continuing to receive some benefits, thus lowering the implicit tax rate on earnings for beneficiaries.

Some research has addressed the effect of financial incentives on employment and earnings, including a number of experimental design evaluations of specific state programs. For a review see Blank, Card, and

${ }^{23}$ Moffitt (1992) provides a review of a variety of incentive effects of the pre-reform welfare system. Changes in welfare programs such as greater eligibility for two-parent families, family caps, and teen residency requirements also potentially affect incentives for marriage and out-of-wedlock childbearing. 
Robins (1999). In general, financial incentives of this type have been found to increase employment and earnings of recipients, but usually with increased program costs and sometimes without increasing overall incomes of recipients.

Additional financial incentives outside the welfare system also serve to increase work incentives for recipients. One of the most important of these factors was the expansion of the Earned Income Tax Credit (EITC) in 1994 and the indexing of benefit levels for inflation. This program works like a negative income tax by providing a refundable tax credit to working families below a certain income level. Given the structure of the tax credit, the marginal tax rate on additional earnings varies. For welfare recipients who are not working or working few hours, the EITC substantially increases the financial returns to work (Acs, Coe, Watson, and Lerman, 1998). Several studies have shown relatively large impacts of increases in the EITC on the labor supply of single women (Eissa and Liebman 1996; Meyer and Rosenbaum, 1999). Recent work has shown significant effect of EITC on wages and the probability that current and former welfare recipients will work (Lemke et al., 1999; Queralt, Witte, and Griesinger, 1999).

Increases in the minimum wage in 1996 and 1997 also may have increased work among welfare beneficiaries, many of whom have low skill levels so that the minimum wage is binding on them. However, minimum-wage increases can also potentially decrease demand for lowskilled labor.

The expansion of child-care subsidies and the changes in child-care policy under PRWORA mean that it is no longer possible to analyze employment incentives of low-income families with children without considering the copayments that families are required to make for child care. One important policy change in many states has been to charge some or all current and former TANF recipients copayments when they receive child-care subsidies. These copayments will partly offset the effects of increased earnings disregards.

As far as we are aware, Acs et al. (1998) provide the most comprehensive analysis of the combined impact of a wide array of social welfare programs, including child-care subsidy programs, on the work incentives of low-income families. They find that work incentives in the 12 ANF states increased substantially after PRWORA. The level of increase in incentives varied substantially with the level of earnings and the level of child-care costs borne by the family.

For example, Acs et al. find that a single TANF mother with two children, one of whom requires full-time child care, would experience a substantial increase in family income as she moved from unemployment 
to part-time minimum-wage work, a moderate increase in income as she moved from part-time to full-time minimum-wage work, and a relatively low increase in income as she moved from full-time minimum-wage work to full-time work at $\$ 9$ per hour. To be more specific, assuming that the mother required full-time paid care for one of her two children and received a subsidy for that care, the family's monthly total income would rise between 36 percent (in California) and 84 percent (in Alabama) as the mother moved from unemployment to part-time minimum-wage work. The family's monthly total income would rise between 17 percent (in Colorado) and 33 percent (in Alabama) as the mother moved from part-time to full-time work paying the minimum wage. Most of these increases in family income are a result of the EITC. Finally, as the mother moved to a full-time job paying $\$ 9$ per hour, total family income would increase between 1 percent (in Massachusetts) and 19 percent (in Alabama). The more modest increases in income as the mother moves into a higher-paying job reflects the phase-out of both state and federal EITC and, in some states, copayments for child care that rise rapidly as family income increases.

\subsubsection{Subsidized Work Expenses As part of their TANF programs,} many states provide subsidies for work-related expenses. This decreases the cost of work, at least over the term of the subsidy, and thus increases the financial returns to work. While the type and extent of these subsidies varies across programs, they typically include in-kind or cash benefits for transportation costs, uniforms and tools, and even licensing. Some of the most important work subsidy benefits are for child care and health insurance while working.

Potentially the most important work subsidy for welfare recipients is for child care. Poor families who do not receive child-care subsidies spend a substantial portion of their income on child care. In 1993, the 39 percent of poor families with preschoolers who paid for child care spent an average of 25 percent of their monthly family income on it (Casper, 1995). Acs et al. (1998) provide a vivid picture of the effect on earnings of child care costs and how subsidies can dilute it.

As noted earlier, most states, but not all, give priority for receiving child-care subsidies to welfare recipients and families who recently left welfare. Families who receive child-care subsidies either pay a much smaller share of their income in child-care expenses or receive what they perceive to be better care for their children. In January 1998, a family of three earning income equal to the federal poverty level in 1997 $(\$ 13,330)$ would have had copayments ranging from 0 percent of family 
income in California to 12 percent in North Dakota (Adams, Schulman, and $\mathrm{Ebb}, 1998) .{ }^{24}$

Another provision of most TANF programs that can reduce the implicit tax on work for welfare recipients is the provision of transitional Medicaid health-insurance benefits. Transitional Medicaid benefits typically continue health-insurance coverage for working former recipient families for a year or more after leaving welfare. Without these provisions, recipients who worked at a level that makes them no longer eligible for welfare benefits would also lose Medicaid benefits. Expansions to the Medicaid program in the late 1980s and early 1990s already made it possible for many children to retain coverage at family income levels above the AFDC eligibility line. However, these expansions did not include adults. Given that many working low-income families do not get health insurance through their employer (either because it is not offered, because they are not eligible, or because of high participation costs), transitional Medicaid benefits should increase the incentive to work. Yelowitz (1995) found that the Medicaid expansions had a positive effect on the labor supply of previously married women but no effect on never-married women.

3.1.3 Mandatory Work Requirements Financial incentives can change the marginal benefit of a first or additional hour of work. Mandatory work requirements, coupled with benefit sanctions for failure to meet these requirements, also increase the marginal benefit of work (or participation in other work-related activities) by decreasing the value of the alternative (not participating). As discussed earlier, many states have increased their initial sanctions for noncompliance, some even reducing benefits to zero. Some recipients are exempt from work requirements, so this incentive depends on the characteristics of the recipient and her family.

\subsection{Incentives Affecting Participation}

In one sense, program changes that increase the incentive to work also serve to decrease participation for those receiving welfare, because as earnings reach a certain level a recipient will no longer be eligible to exit the program. However, increases in earnings disregards allow recipients to earn more and continue to receive welfare, thus prolonging the duration of welfare receipt. There are some additional facets of recent reform that also can affect the probability of participation in TANF. These effects may be both intended and unintended consequences of these poli-

24 The families may have additional costs on top of their copayments. 
cies. The most important changes include the introduction of benefit time limits, changes in the "environment" of welfare (including the extent of requirements and the culture of welfare programs), and access to child-care subsidies.

While there has been little research yet on the extent to which specific changes have affected participation, there have been several studies trying to explain the recent caseload declines more broadly. These studies use time-series caseload data to investigate the effects of policy, without separating entry and exit effects or specific policy changes (Council of Economic Advisors, 1997; R. Blank, 1997). The studies find that welfare waivers (combining all types of policy changes) caused a significant decline in caseloads. Moffitt (1999) finds similar results but goes on to use micro-level data to examine the effect of waivers on labor supply, earnings, and income, finding that waivers led to increased weeks worked and hours, but not to increased earnings or wages. Attempts in these studies to separate out the effect of specific types of waiver policies, such as family caps vs. time limits, have been inconclusive. In their most recent study, the Council of Economic Advisors uses caseload data for 1976 through 1998 to sort out the relative importance of the strong economy and welfare reform for the decline in caseloads since 1994. They conclude that most of the decline in caseloads that occurred for 1993-1996 was due to the strong economy. However, they feel that roughly one-third of the decline from 1996 to 1998 was due to welfare reform (Council of Economic Advisors, 1999).

3.2.1 Time Limits Reducing the lifetime allowable months of benefit receipt (and/or months of receipt within a certain time period) provides an incentive for recipients to leave welfare sooner than they would have otherwise and decreases the incentive to participate overall. Given a limit on total months of receipt, a recipient deciding to continue receiving TANF next month will have one less month of potential TANF benefits in the future. Before time limits, recipients would compare the present discounted value of potential income streams with and without continuing benefit receipt next month. After time limits, future benefit receipt is now lower if benefits are continued, which decreases the present discounted value of that income stream, decreasing the probability of welfare receipt next month. For recipients who expect to need cash assistance in the future, the probability of continuing benefit receipt is unambiguously lower when there are time limits than in a no-time-limits world. The extent to which time limits affect participation depends on many factors, including how families view their chances of exhausting benefits, their potential nonwelfare income, and their discount rate. 


\subsubsection{Changes in Program "Environment" As described earlier, many} state TANF programs have increased activity requirements for benefit receipt over those for AFDC. The JOBS program had job preparedness requirements for some recipients, but most TANF programs have increased activity requirements far beyond those under the JOBS program. States have increased the number of hours of required activities. They have also restricted the choice of activities, and increased the pool of recipients required to be active. In addition, non-work-related requirements have increased substantially. Some of these include immunization and school attendance for children, fingerprinting of recipients, more frequent recertifications of exemptions, and stricter paternity establishment rules.

The environment and culture of many welfare offices has changed. PRWORA stresses the idea that both parties (the government and the recipient) have responsibilities. As noted earlier, most states now require recipients to sign some form of personal responsibility plan that emphasizes that welfare receipt is a contract: benefits are provided in return for the recipient's pledge to carry out certain activities. For some, the increase in required activity changes their valuation of benefit receipt enough for them to end welfare receipt or not begin participation. Diversion policies that require applicants to perform job search before being eligible may also deter potential applicants from joining the program.

Edin and Lein (1997) document extensive "off-the-books" work done by welfare recipients. Such work may well conflict with the now higher participation requirements and lead recipients to leave welfare.

3.2.3 Access to Child-Care Subsidies As discussed earlier, in some, but not all, states, families face an important incentive to enter welfare-the receipt of priority for child-care subsidies. As noted earlier, many states have waiting lists for child-care subsidies for families who did not receive cash assistance. In such states, some parents frustrated by long waiting lists may join the welfare rolls to get child-care assistance. This could also be true for some other forms of work assistance, but likely to a lesser extent, since other benefits such as education and training assistance or Medicaid coverage are more widely available to low-income families that do not receive cash assistance.

An important potential side benefit of programs such as those in Colorado, Illinois, Rhode Island, and Wisconsin that sever the link between cash assistance and priority for child care is to decrease the incentive to participate in the TANF program. One could also, of course, argue for breaking the link on equity grounds. 


\subsection{Trying to Sort It All Out}

Researchers are only now beginning to try to sort out the independent effects of the different policy changes that have accompanied PRWORA on the employment and earnings of low-income families. Devolution, when coupled with the increasing diversity of state and local programs, means that such efforts require not only longitudinal data that span a period before and after welfare reform, but also detailed local-level policy and administrative information. The wide variety of policy and administrative changes means that such work needs to be unusually comprehensive in its inclusion of policy and administrative variables.

As far as we are aware, there are currently results for only four studies that use data for both a period prior to and one after welfare reform and that take into account a wide range of changes associated with welfare reform (Chipty, Witte, and Queralt, 1999; Lemke et al., 1999; Queralt, Witte, and Griesinger, 1999; Witte, Queralt, Chipty, and Griesinger, 1999). These studies use large samples of child-care subsidy recipients in Massachusetts, a state that began welfare reform prior to PRWORA, and Florida, a state that implemented welfare reform immediately after PRWORA became effective. The studies consider the effects of a wide array of cash-assistance and child-care policy and administrative changes that accompanied welfare reform, the effect of two minimum wage increases, the effect of the increased generosity of the EITC, and the effect of tax credits for hiring current and former welfare recipients. They also control for an unusually wide array of personal and family characteristics and for the nature of the local labor and child-care markets.

Overall, these studies, when coupled with other work, suggest the following tentative conclusions. Increased funding for child-care subsidies and the increased generosity of the EITC are most consistently related to increases in the probability of work and earnings for current and former welfare recipients and for other low-income families with children. High levels and rates of increase in copayments for child-care subsidies may well have significant work disincentive effects. Both time limits and activity requirements are associated with significant increases in the probability that a welfare recipient will work, but are also associated with significantly lower wages for those that do work. This latter effect may result because families have lower reservation wages when faced with time limits or activity requirements. Increases in the minimum wage, sanctions, and employer tax credits for hiring low-income workers may have no significant effect on either the probability of work or earnings. 


\subsection{Child-Care Choice}

One of the main objectives of federal child-care subsidy policy is to give families a choice of child-care arrangements. This objective was codified in the final CCDF regulations. Whether a policy expands someone's choices is empirically difficult to measure, since all one sees is the arrangement actually chosen and not the range of choices the parent faces. One way of looking at the effect of subsidies on the range of choices is to see if there are systematic differences in the arrangements chosen by families who use subsidies and those who do not. A problem with this approach is that families who use subsidies may be different in other ways (e.g., preferences for child care) than families who do not receive subsidies. Fuller et al. (1999) find that families who use subsidies are more likely to use center-based care than other families. Given that the overwhelming majority of copayment schedules are based on gross family income and family size, parents with a subsidy face the same price for all types of care. Faced with the same price for all types of care, it is not too surprising that subsidized families are more likely to choose center care, which is generally believed to be of higher quality on average.

\section{RESULTS FROM THE NATIONAL SURVEY OF AMERICA'S FAMILIES}

As welfare reform and a booming labor market have led to a dramatic drop in the number of families on welfare, there is great interest in how families who have left the welfare rolls are faring. In this section, we present results from the National Survey of America's Families (NSAF) that provide a national picture of work and child-care use among former welfare recipients in 1997, the early period after the passage of PRWORA. ${ }^{25}$

There is also a great deal of concern about the effects of welfare reform on children. As more single mothers become employed due to welfare reform, it is likely that more children will be cared for by someone other than their mothers. Over half (56 percent) of employed former welfare recipients have at least one child under the age of five. A first step in understanding how welfare reform is affecting children is to know who cares for them. In this section, we describe how young children of em-

25 A large number of studies have provided descriptive information on former recipients' status in particular parts of the country at the state or local level. For reviews see Brauner and Loprest (1999) or U.S. General Accounting Office (1999). 
ployed former welfare recipients are cared for, and how care for these children differs from the care received by other low-income children.

The NSAF is a nationally representative survey of the civilian, noninstitutionalized population under age 65 and their families. Interviews were conducted between February and November 1997. The survey collected economic, health, and social characteristics for 44,000 households, over sampling households with incomes under 200 percent of poverty and households in each of 13 ANF states. The $1997 \mathrm{NSAF}$ provides information for the early period of welfare reform, when some states were well into their reforms while other states had only just begun. A second cross-sectional wave of the survey is being conducted in 1999.

\subsection{Employment and Earnings of Welfare Leavers}

With the NSAF data; we are able to examine the status of former welfare recipients in $1997 .{ }^{26}$ The sample of 1,289 families on which we focus consists of former recipients who stopped receiving benefits at some point between 1995 and 1997 and are not receiving benefits at the time of the interview. While this analysis combines leavers who left only several months ago with those who left more than a year ago, separately the sample size for either one of these groups alone becomes small. ${ }^{27}$

\subsubsection{Employment of Former Recipients A first piece of evidence about} the role of work in leavers' transition off welfare is the reasons they give for leaving. The NSAF data give us the leavers' own reports of why they left welfare. Work is the most common reason among this group of leavers. ${ }^{28}$ More than two-thirds (69 percent) reported leaving welfare because of increased earnings or hours on an ongoing job or because of a new job. The second most common reason for leaving, reported by 10 percent of leavers, was administrative problems or hassles.

While these results are not strictly comparable to past research on reasons for leaving welfare, they suggest that a higher percentage of recipients are leaving for work now than in the past. Pavetti (1993) found that 46 percent of recipients left welfare due to an increase in earnings. 26 A full description of the well-being of former welfare recipients can be found in Loprest
(1999).

${ }^{27}$ The NSAF questions about current and former welfare receipt are asked of the adult in the family who is most knowledgeable about the children. A small number of fathers are included.

${ }^{28}$ Survey respondents gave open-ended answers that were then coded into categories. Leavers could report multiple reasons for leaving, but only about 5 percent did. This description of reasons for leaving excludes about 30 percent of leavers who did not report a reason. 
TABLE 3

Job Characteristics of Those Currently Working

\begin{tabular}{|c|c|c|}
\hline Characteristic & $\begin{array}{l}\text { Former } \\
\text { recipients } \\
(\%)\end{array}$ & $\begin{array}{c}\text { Low-income } \\
\text { mothers }{ }^{(a)} \\
<200 \% \text { poverty } \\
(\%)\end{array}$ \\
\hline Median hourly wage & $\$ 6.61$ & $\$ 6.06$ \\
\hline $\begin{array}{l}\text { Hours of work: } \\
<20 \\
20 \text { to } 35 \\
\text { More than } 35\end{array}$ & $\begin{array}{r}6.1 \\
24.5 \\
69.4\end{array}$ & $\begin{array}{l}10.4^{(b)} \\
25.3^{(b)} \\
64.2^{(b)}\end{array}$ \\
\hline $\begin{array}{l}\text { Mostly work between } 6 \text { A.M. } \\
\text { and } 6 \text { P.M. }\end{array}$ & 71.8 & 74.5 \\
\hline $\begin{array}{l}\text { Coordinated schedule with } \\
\text { spouse for child care }\end{array}$ & 62.4 & 52.1 \\
\hline $\begin{array}{l}\text { Multiple jobs (two or more) } \\
\text { Health insurance through employer }\end{array}$ & $\begin{array}{r}8.0 \\
23.2\end{array}$ & $\begin{array}{c}9.0 \\
35.8^{(b)}\end{array}$ \\
\hline
\end{tabular}

Source: Urban Institute calculations from the National Survey of America's Families.

(a) Low-income mothers include women with children under 18 who have not received welfare benefits since 1995 and have family incomes in 1996 under 200 percent of poverty.

(b) Significant difference from former recipients at the $90 \%$ confidence level.

(c) Asked only of two-parent families with both working and a child under 13 years old. Numbers may not add to 100 percent due to rounding or in some cases a small percentage of "don't know" or "refuse" answers.

This percentage leaving for work is, in turn, higher than results for earlier periods (Ellwood, 1986). ${ }^{29}$

A majority of former recipients were working at the time of the interview in 1997. Sixty-one percent of leavers who were still off welfare at the time of the interview were working. Another 16 percent were actively looking for work. Since a third of former recipients reported living with a spouse or partner, the number of former recipient families with a working adult is even higher. Three-quarters of former recipients are in families where either they or their partner was working. Most employed former recipients were working full time. Sixty-nine percent of former recipients with jobs were working 35 or more hours a week (Table 3 ).

Employed former recipients' jobs are best characterized as entry-level. Only 23 percent have health insurance through their employer. Also,

29 The data used in Pavetti (1993) differ in many ways from the NSAF, so comparisons must be made with caution. The Ellwood study found an even lower percentage of recipients leaving due to work than did Pavetti. Some of this difference is due to actual increases in leaving for earnings, and the rest due to differences in data sources and methods. 
more than a quarter work mostly on night shifts (outside of the hours of 6 A.M. to P.M.). Of two-parent families where both are working and have a child under 13, 62 percent are coordinating their schedules for childcare reasons. In addition, 8 percent of former recipients are holding more than one job.

Most former recipients work in low-wage jobs. The median hourly wage of former recipients (excluding the self-employed) in 1997 is $\$ 6.61$. While this is higher than the minimum wage of $\$ 4.75$ (at the time of the interview), it is still only roughly the 20th percentile of hourly wages for all hourly workers. So while many former recipients are working, they are entering at the low end of the labor market.

Former recipients' hourly wages do not give the whole picture of families' reliance on work. Combining the earnings of former recipients with their spouses' earnings, we find median monthly earnings for former recipient families of $\$ 1,149$ per month. On an annualized basis, this level of median monthly earnings is $\$ 13,788$, roughly the 1997 poverty level for a family of three. This does not include other sources of income, notably the Earned Income Credit, which can add substantially to income. It also assumes a steady level of labor supply across the year, which other research indicates is unlikely for welfare recipients (Rangarajan, Schochet, and Chu, 1998).

\subsubsection{Comparison with Other Low-Income Families To provide a con-} text for interpreting these employment levels and wage and job characteristics, we look at how former recipients are doing in comparison with low-income families with children who have not recently received welfare. We define this latter group as women with children under age 18 who have not recently (since 1995) been on welfare and whose family income in 1996 was under 200 percent of poverty. This group comprises 30 percent of all women with children under 18 .

More former recipients are working than mothers in other low-income families: 61 percent compared to 54 percent. However, many more former recipients are single parents. When we consider the percentage of families with at least one adult employed, a somewhat higher percentage of other low-income families have workers: 86 percent compared to 75 percent. Overall, the difference in the probability of work is accounted for by the difference in family types.

The types of jobs former recipients are holding are very similar to those held by other low-income women with children who have not recently received welfare. The occupation and industry mix, the amount of night-shift work, and the number holding multiple jobs are all similar (Table 3). The biggest difference is in the percentage with health insur- 
ance from their employer: 23 percent of former recipients compared to 36 percent of other low-income mothers. In addition, although the median hourly wage of former recipients is low (\$6.61), it is higher than that of other low-income mothers $(\$ 6.06)$.

These results suggest that while former recipients are entering the labor market at low wages and in entry-level jobs, they are squarely within the range of jobs held by the large group of low-income mothers with children who have not recently received cash assistance. It is important to remember that this group of leavers is an early cohort. Future cohorts of leavers may be less job-ready or may be facing a less hospitable labor market.

\subsection{Child-Care Arrangements of Former Welfare Recipients}

The analysis of child-care arrangements is based on a different NSAF sample than the analysis of welfare leavers' employment outcomes. The unit of observation is the child, rather than the parent. The sample includes children under the age of five with employed parents. ${ }^{30}$

For this analysis, we focus only on the primary child-care arrangement, that is, the arrangement in which the child spent the largest number of hours while the parent was working. We divide nonparental arrangements into four primary care categories. The first three are nonparental care categories: center-based care (Head Start, preschool, prekindergarten, nursery school, before- and after-school programs); family day care (care by nonrelatives outside the child's home); and relative or baby-sitter care (relative care, and nonrelative care in the child's home). ${ }^{31}$

Employed respondents who did not report using any of the nonparental arrangements described above are classified as having a parental arrangement. The share of children of employed parents with parental arrangements in the NSAF (23 percent) is very close to the share (24 percent) of preschool children in the 1994 Survey of Income and Program Participation who were cared for by their mother or their father while their mother was working (Casper, 1997).

Quality ranges widely within each type of child-care arrangement, so

30 "Parent" refers to the most knowledgeable adult in the household, who was the survey respondent. For the sample used for child-care analyses, 83 percent of the parents were mothers. In the remainder of the cases, the respondent was the father, stepparent, grandparent, or other responsible adult. For more information about the NSAF child-care survey data, see Schmidt, Sonenstein, and Capizzano (1999).

31 Babysitters and nannies who come to the child's home were grouped with relatives because only 4 percent of all low-income families and 2 percent of current or former welfare recipients used those arrangements. The before- and after-school program question was only asked of parents of 3-4-year-old children. For that age group, the programs typically consist of center-based programs that meet before or after half-day preschool programs. 
arrangement is not a proxy for quality. Policies governing quality treat different kinds of arrangements differently, so understanding which arrangements children are in could tell us something about which policy levers could be used to improve quality.

4.2.1 Child-Care Arrangements. Table 4 shows the child-care arrangements of 0-4-year-old children separately by four welfare status and income categories. These categories include two breaks for those who have ever been on cash assistance: current recipients and those who have left AFDC since January 1995. The other two categories include respondents that have never received cash assistance: low-income families (families with incomes less than $200 \%$ of poverty) and high-income families (families with incomes greater than $200 \%$ of poverty).

It is important to emphasize that the sample includes only employed parents, and that the current-welfare-recipients category includes only employed welfare recipients. Only 17 percent of the children aged 0-4 that were currently receiving welfare had employed parents. In contrast, 57 percent of the children whose families had left welfare since 1995, 60 percent of children whose families had left welfare before 1995, and 46 percent of low-income children whose families had never been on wel-

TABLE 4

Child-Care Arrangements by Welfare Status and Income ${ }^{(\mathrm{a})}$

\begin{tabular}{lcccc}
\hline & \multicolumn{4}{c}{ Primary arrangement } \\
\cline { 2 - 3 } Welfare category & $\begin{array}{c}\text { Center-based } \\
\text { care }\end{array}$ & $\begin{array}{c}\text { Family } \\
\text { day care }\end{array}$ & $\begin{array}{c}\text { Relative } \\
\text { babysitter }\end{array}$ & $\begin{array}{c}\text { Parent } \\
\text { care }\end{array}$ \\
\hline Currently receiving welfare & $33 \%$ & $17 \%$ & $35 \%$ & $16 \%$ \\
& $(6.6)$ & $(3.9)$ & $(5.5)$ & $(4.0)$ \\
Left welfare since 1995 & $34 \%$ & $17 \%$ & $33 \%$ & $17 \%$ \\
& $(4.7)$ & $(4.4)$ & $(4.3)$ & $(4.8)$ \\
Left welfare before 1995 & $37 \%$ & $16 \%$ & $24 \%$ & $22 \%$ \\
Never on welfare; Income & $(4.2)$ & $(3.5)$ & $(4.3)$ & $(3.7)$ \\
$\quad<200 \%$ of poverty & $21 \%$ & $14 \%$ & $33 \%$ & $31 \%$ \\
Never on welfare; Income & $(2.3)$ & $(2.8)$ & $(3.0)$ & $(2.5)$ \\
$>200 \%$ of poverty & $33 \%$ & $16 \%$ & $28 \%$ & $23.0 \%$ \\
& $(1.9)$ & $(1.5)$ & $(1.6)$ & $(1.9)$ \\
\hline
\end{tabular}

(a) Standard errors in parentheses. 
fare had employed parents. Despite the small proportion of employed welfare recipients, we are very much interested in this group. These respondents give us an indication of the types of care arrangements being used by welfare recipients - which is of great interest as recipients are moved into more extensive employment because of TANF work requirements.

Table 4 indicates that the child-care arrangements of current welfare recipients, former welfare recipients, and high-income children do not differ significantly. The low-income children whose parents have never been on welfare, however, do stand out from these other groups: they are more likely to be placed in parental care and less likely to be placed in center-based care than the other groups of children. This may reflect the lesser availability of child-care subsidies for this group.

The use of family day-care homes or relative or baby-sitter care does not differ significantly by welfare status and income. While there has been much discussion in the child-care policy arena about welfare recipients depending heavily on relatives to care for their children, our results indicate that this group is no more likely to use this form of care than other groups.

\section{CONCLUSIONS}

During the twentieth century, the United States has substantially reformed its social welfare system every 30 years. These reforms have all come during unusual economic times. The first reform occurred during the great depression of the 1930s. This reform greatly increased the role of the federal government in welfare policy and established a cash assistance program for low-income families with children. The reforms of the thirties shaped welfare policy for the next 30 years.

The next wave of reform, called the "War on Poverty," came during the sustained economic expansion of the 1960s. This reform substantially expanded the social welfare net and the federal role, creating such programs as Head Start, Medicaid, and Medicare. This reform began the trend to provide an increasing proportion of welfare benefits in kind rather than in cash.

The most recent wave of reforms, two aspects of which we examine in this paper, came during the economic expansion of the 1990s. This wave of reform was quite unlike the two that came before it. It sought to limit the federal role in social welfare policy to providing broad policy and administrative guidelines and block grants to states. In response (and through earlier federal waivers), state programs have changed markedly from pre-reform systems. While most are emphasizing work, they do so 
in many ways, with different combinations of requirements, incentives, and services. Some states have devolved substantial policy and administrative responsibility to local government. Some social welfare functions have been either privatized or "nonprofitized."

Under the latest set of reforms, state and local governments have shifted substantial amounts of spending from cash assistance to direct services. Most states adopted a work-first approach to welfare reform that sought to move those that received cash assistance into jobs as rapidly as possible. Many states have started diversion programs to reduce the number of families entering cash assistance programs. Much increased state spending has gone to provide child-care services not only to recipients of cash assistance, but also to other low-income families. States have reduced the number of families receiving cash assistance and increasing the proportion of cash assistance recipients that work.

Just as Medicaid has gradually been divorced from cash assistance, many states are now severing the link between child-care services and cash assistance. As noted in the title, the new welfare reform may best be characterized as Aid to Children with Working Families. Judging from Congress's stated goal when passing PRWORA, an unintended consequence of the welfare reform of the 1990s has been to place increasing numbers of poor children in more formal child-care settings.

We still are in the early stages of the current welfare reform, and the shape of the reform to date varies from state to state and (in states that have devolved power) from locality to locality. Some overall trends in social welfare policy are now becoming apparent. First, as was expected, devolution has led to greater diversity in both cash-assistance and childcare policies. Some states still run both cash-assistance and child-care programs much like those that existed prior to the 1990s, but most states now have social welfare programs in place that are markedly different from their programs of the first half of the 1990s.

States have found a variety of ways to increase work and decrease benefit receipt. In addition to mandated changes that require work activities and limit benefit receipt, states have used other policy and administrative changes to move families to work. Some of these include shorter time limits and fewer exemptions to work requirements than allowed under PRWORA. States have also increased financial incentives by allowing recipients who work to keep more benefits and by providing more work supports. The whole structure and environment of many welfare programs have changed to encourage work and discourage cash assistance.

Welfare reform increased the federal child-care funding available to states and allowed states to spend federal TANF funds on child care. In response, states have increased or maintained their own child-care fund- 
ing, and many have spent federal TANF funds on child care. Nonetheless, most states still do not have enough funds to provide subsidies for all eligible applicants. Most still give priority to welfare recipients, and working poor families often have to wait to receive subsidies. A handful of states have guaranteed subsidies to all eligible families regardless of welfare status.

PRWORA also gave states some additional flexibility in setting provider reimbursement rates and family copayments. In addition, by simplifying the rules and regulations for child-care subsidies, PRWORA better enabled states to consolidate the administration of child-care programs. The additional flexibility granted by the law encouraged some states to further devolve child-care administration and policymaking to the local level.

The welfare reform of the 1990s is still an unfinished product. It is not clear how families with substantial barriers to employment will be moved into work. Child-care policy is still not fully integrated or completely thought through. It is not clear how local governments will deal with the substantial set of new responsibilities that have been thrust upon them. While economic wisdom indicates that you cannot effectively redistribute income at the local level, there are also arguments for the increased efficiency of local-level programs to meet direct service needs. It remains to be seen how well local governments can provide cash and in-kind assistance.

To date, the welfare reform of the 1990s has taken place in a time of economic expansion when substantial numbers of new jobs are being created. It is not clear how well suited the new set of welfare policies is for an economic downturn. However, it seems likely that the federal block grant, when coupled with downturns in revenue for state and local government, will mean that welfare expenditures will provide less of an economic stabilizer than the AFDC entitlement system did.

Congress is scheduled to revisit PRWORA in 2002. At that time, it is important that clearer answers be available to some of these nagging questions.

\section{REFERENCES}

Acs, Gregory, Norma Coe, Keith Watson, and Robert I. Lerman (1998). "Does Work Pay? An Analysis of the Work Incentives under TANF." Assessing the New Federalism Occasional Paper no. 9. Washington: Urban Institute.

Adams, Gina, Karen Schulman, and Nancy Ebb (1998). Locked Doors: States Struggling to Meet the Child Care Needs of Low-Income Working Families. Washington: Children's Defense Fund.

Administration for Children and Families. (1998a). Child Care and Development 
Grant: Report of State Plans for the period 10/01/97 to 9/30/99. Washington: U.S. Department of Health and Human Services.

_ . (1998b). "Temporary Assistance for Needy Families (TANF) Program: First Annual Report to Congress," http://www.acf.dhhs.gov/news/welfare/ congress/index.htm/, accessed July 24. 1999.

- (1999a). "TANF Financial Data-Quarterly TANF Data for States," http:// www.acf.dhhs.gov/programs/ofs/data/, accessed August 16, 1999.

_ . (1999b). "State Spending under the New Welfare Reform Law," http:// www.acf.dhhs.gov/programs/ofs/data/q199/fy199.htm/, accessed July 24, 1999.

- (1999c). "Summary, Final Rule: Temporary Assistance for Needy Families (TANF) Program. http://www.acf.dhhs.gov/programs/ofs/data/q199/fy199 htm/, accessed July 24, 1999.

American Public Welfare Association (1998). Meeting the Child Care Challenge: State Child Care Status Survey. Washington: APWA Government Affairs Department. Azer, Sherri (1999). Overview of States with Differential Reimbursements, Boston: Center for Career Development in Early Care and Education.

Blank, Rebecca (1997). "What Causes Public Assistance Caseloads to Grow?" NBER Working Paper no. 6343.

Blank, Rebecca, David Card, and Philip K. Robins (1999). "Financial Incentives for Increasing Work and Income Among Low-Income Families." Joint Center for Poverty Research Working Paper no. 1.

Bloom, Dan (1999). The Cross-Study of Time-Limited Welfare: Welfare Time Limits: An Interim Report Card. New York: Manpower Demonstration Research Corporation.

Brauner, Sarah, and Pamela Loprest (1999). "Where Are They Now? What States' Studies of People Who Left Welfare Tell Us." New Federalism: Issues and Options for States, no. A-32. Washington: Urban Institute.

Casper, Lynne M. (1995). "Whose Paying for Our Preschoolers?" Current Population Reports P70-62. Washington: U.S. Census Bureau.

. (1997). "Who's Minding Our Preschoolers? Fall 1994 (Update)." Current Population Reports P70-62. Washington: U.S. Census Bureau.

Chipty, Tasneem, and Ann Dryden Witte (1997). "A Study of the Effect of Minimum Standards on Product Offerings, Quality Distributions." NBER Working Paper no. 6104.

. (1999). "What is Happening to Families Receiving Cash Assistance?: A Longitudinal Study of the Early Stages of Welfare Reform." Paper presented at the annual meeting of the American Economic Association, New York.

Chipty, Tasneem, Ann Dryden Witte, and Magaly Queralt (1999). "What Is Happening to Families Receiving Public Assistance?" Paper presented at the Annual Meeting of The American Economic Association, New York City, January, 1999.

Committee on Ways and Means (1996). 1996 Green Book. Washington: U.S. Government Printing Office.

C. (1998). 1998 Green Book. Washington: U.S. Government Printing Office.

Council of Economic Advisors (1997). "Explaining the Decline in Welfare Receipt, 1993-1996: Technical Report." Executive Office of the President of the United States.

- (1999). The Effects of Welfare Policy and the Economic Expansion on Welfare Caseloads: An Update. Washington: Council of Economic Advisors.

Department of Health and Human Services (1998a). "45 CFR Parts 98 and 99: 
Child Care and Development Fund; Final Rule." Federal Register, July 24: 39,935-39,998.

Department of Health and Human Services (1998b). "Child Care and Development Block Grant Report of State Plans." http://www.acf.dhhs.gov/programs/ $\mathrm{ccb} /$ programs/plan/, accessed July 24, 1999.

Edin, Kathryn, and Laura Lein (1997). Making Ends Meet: How Single Mothers Survive Welfare and Low-Wage Work. New York: Russell Sage.

Eissa, Nada, and Jeffrey B. Liebman (1996). "Labor Supply Response to the Earned Income Tax Credit." Quarterly Journal of Economics 112(no. 2): 605-637.

Ellwood, David (1986). "Targeting 'Would-Be' Long-Term Recipients of AFDC." MPR no. 7617-953. Princeton, NJ: Mathematical Policy Research.

Fuller, Bruce, Sharon Lynn Kagan, Jan McCarthy, Gretchen Caspary, Darren Lubotsky, and Laura Gascue (1999). "Who Selects Formal Child Care? The Role of Subsidies as Low-Income Mothers Negotiate Welfare Reform." Paper presented at Society for Research in Child Development Annual Meeting, Policy Analysis for California Education, Berkeley, CA.

Gallagher, L. Jerome, Megan Gallagher, Kevin Perese, Susan Schreiber, and Keith Watson (1998). "One Year after Federal Welfare Reform: A Description of State Temporary Assistance for Needy Families (TANF) Decisions as of October 1997." Assessing the New Federalism Occasional Paper no. 6. Washington, DC: Urban Institute.

Greenberg, Mark. (1996). "A Summary of Key Child Care Provisions of H.R. 3734: The Personal Responsibility and Work Opportunity Reconciliation Act of 1996." http://www/clasp.org/pubs/childcare/clkccp.html. Accessed August 22, 1999.

Greenberg, Mark, and Steve Savner (1998). The Final TANF Regulations: A Preliminary Analysis. Washington: Center for Law and Social Policy.

Holcomb, Pamela A., La Donna Pavetti, Caroline Ratcliffe, and Susan Riedinger (1998). Building an Employment Focused Welfare System: Work First and Other Work-Oriented Strategies in Five States. Washington: Urban Institute.

Horrace, William, Peter Schmidt, and Ann Dryden Witte (1998). "Sampling Errors and Confidence Intervals for Order Statistics: Implementing the Family Support Act and Welfare Reform," Journal of Economic and Social Measurement 24(no. 3/4):181-207.

Lemke, Robert, Magaly Queralt, Ann Witte, Robert Witt, and Tasneem Chipty (1999). "Impacts of Child Care Subsidies and Early Childhood Education Programs on Massachusetts' Current and Former TAFDC Recipients under Welfare Reform." Working Paper. Department of Economics, Wellesley College. Long, Sharon K. (1999). "Child Care Assistance under Welfare Reform: Early Responses by the States." March 16, 1999 Testimony to U.S. House Committee on Ways and Means Subcommittee on Human Resources. Washington: Urban Institute.

Long, Sharon K., and Sandra J. Clark (1998). "The New Child Care Block Grant: State Funding Choices and Their Implications." New Federalism: Issues and Options for States no. A-12. Washington: Urban Institute.

Long, Sharon K., Gretchen G. Kirby, Robin Kurka, and Shelley Waters (1998), "Child Care Assistance under Welfare Reform: Early Responses by the States." Assessing the New Federalism Occasional Paper no. 15. Washington: Urban Institute.

Loprest, Pamela (1999). "Families Who Left Welfare: Who Are They and How 
Are They Doing?" Assessing the New Federalism Discussion Paper no. 99-02. Washington: Urban Institute.

Maloy, Kathleen A., La Donna A. Pavetti, Peter Shin, Julie Darnell, and Lea Scarpulla-Nolan (1998). A Description and Assessment of State Approaches to Diversion Programs and Activities under Welfare Reform. Washington: The George Washington University School of Public Health and Services Center for Health Policy Research.

Meyer, Bruce, Dan Rosenbaum, "Welfare, the Earned Income Tax Credit and the Labor Supply of Single Mothers." NBER Working Paper 7363, September, 1999.

Moffitt, Robert (1992). "Incentive Effects of the U.S. Welfare System: A Review." Journal of Economic Literature XXX(no. 1):1-61.

(1999). "The Effects of Pre-PRWORA Waivers on AFDC Caseloads and Female Earnings, Income, and Labor Force Behavior." Johns Hopkins University Working Paper.

Nathan, Richard P., and Thomas L. Gais (1999). Implementing the Personal Responsibilities Act of 1996: A First Look. Albany, NY: The Nelson A. Rockefeller Institute of Government, State University of New York.

National Association of State Budget Officers (1998). "Fiscal Survey of the States, Special Feature: Welfare Reform." http://www.nasbo.org/. Accessed August $22,1999$.

Office of the Inspector General (1998). "States' Child Care Certificate Systems: An Early Assessment of Vulnerabilities and Barriers." Washington: Department of Health and Human Services.

Pavetti, La Donna (1993). "The Dynamics of Welfare and Work: Exploring the Process by Which Women Work Their Way off Welfare." Cambridge, MA: Harvard University. Unpublished doctoral dissertation (no. D-93-1).

Queralt, M., A.D. Witte, and H. Griesinger (1999). "Changing Policies, Changing Impacts: Employment and Earnings of a Child Care Subsidy Recipients in the Era of Welfare Reform." Wellesley College Working Paper.

Quint, Janet, Kathryn Edin, Maria L. Buck, Barbara Fink, Yolanda C. Podilla, Olis Simmons-Hewitt, and Mary Eustace Valmont. (1999). Big Cities and Welfare Reform. New York: MDRC.

Rangarajan, Anu, Peter Schochet, and Dexter Chu (1998). "Employment Experiences of Welfare Recipients Who Find Jobs: Is Targeting Possible?" Princeton, NJ: Mathematica Policy Research. Paper no. 8428-600.

Schmidt, Stefanie, R., Freya L. Sonenstein, and Jeffery Capizzano (1999). "Do the Child Care Arrangements of Current and Former Welfare Recipients Differ from Other Low-Income Families?" Washington: Urban Institute. Urban Institute Working Paper.

Schott, Liz, Ed Lazere, Heidi Goldberg, and Eileen Sweeney (1999). Highlights of the Final TANF Regulations. Washington: Center on Budget and Policy Priorities.

U.S. General Accounting Office (1994). Child Care: Working Poor and Welfare Recipients Face Service Gaps. GAO/HEHS-94-87. Washington.

- (1998a). Welfare Reform: States' Efforts to Expand Child Care Programs. GAO/ HEHS-98-27. Washington: U.S. Government Printing Office.

(1998b). Welfare Reform: States Are Restructuring Programs to Reduce Welfare Dependence. GAO/HEHS-98-109. Washington. 
(1999). Welfare Reform: Information on Former Recipients' Status. GAO/ HEHS-99-48. Washington: U.S. Government Printing Office.

Witte, Ann Dryden, Magaly Queralt, Tasneem Chipty, and Harriet Griesinger (1999). "Unintended Consequences?: The Welfare Reform 'Package' and the Earnings of Low-Income Women." Wellesley College Working Paper.

Yelowitz, Aaron (1995). "The Medicaid Notch, Labor Supply, and Welfare Participation." Quarterly Journal of Economics, 110(no. 4):909-940.

Zedlewski, Sheila R., Pamela A. Holcomb, and Amy-Ellen Duke (1998). "Cash Assistance in Transition: The Story of 13 States." Assessing the New Federalism Occasional Paper no. 16. Washington: Urban Institute. 